\title{
1 The Tianjin Eco-City model in the academic literature on urban
}

2 sustainability

3 Yinghao Li ${ }^{\mathrm{a}, 1}$, Hadrien Commenges ${ }^{\mathrm{a}, \mathrm{b}}$ Frédérique Bordignon ${ }^{\mathrm{c}}$, Céline Bonhomme ${ }^{\mathrm{a}}$,

4 José-Frédéric Deroubaix ${ }^{\mathrm{a}}$

5 a University Paris-Est, Laboratoire Eau Environnement et Systèmes Urbains, Ecole des Ponts ParisTech.

6 Corresponding author.Tel : +862769600275.Email :yinghao.li@mail.com

$7 \quad{ }^{\mathrm{b}}$ UMR 8504 Géographie-cités, Université Paris 1, Université Paris 7, CNRS

$8 \quad{ }^{\mathrm{c}}$ Ecole des Ponts ParisTech, Centre de documentation

\section{Abstract}

10 Recent intensive eco-city development in China has been accompanied by rising 11 enthusiasm for environmental sustainability indicators. Whilst there are calls for the 12 indicators to be standardised, and criticism of the difficulties in applying them, little 13 effort has been made to understand their scientific rationale. This article employs a 14 comprehensive bibliometric analysis to investigate the use of environmental 15 indicators from the Tianjin Eco-City Key Performance Indicators by the international 16 scientific community working on urban sustainability. The findings draw a clear 17 picture of the place of Tianjin Eco-City's indicators in the international scientific 18 literature. China's ecological problems are found to attract interest not only from 19 domestic researchers but also researchers outside the country. The indicators are used 20 not only for urban planning and management but also for a wide range of urban21 related and non-urban-related purposes. The scientific rationale of the eleven 22 indicators is specifically addressed, revealing a number of underlying questions about 23 the Tianjin Eco-City indicators.

\section{$24 \quad$ Key words}

25 Urban sustainability, environmental indicators, Tianjin Eco-City KPI, scientific

26 rationale, bibliometric analysis, geographical analysis

\section{$27 \quad 1$ Introduction}

28 Following the recent promotion of eco-cities, there is increasing interest among 29 researchers and policy makers in sustainability assessment. A sustainable city can be 30 defined by analogy with the Brundtland Commission's definition of sustainable 31 development (WCED, 1987) as a city that ensures that development meets the needs 32 of the present without compromising the ability of future generations to meet their 33 own needs. Conventionally incorporated into the triple bottom line of environmental, 34 social and economic criteria, the substantive purpose of sustainability assessment is to 35 provide policymakers and city planners with tools for evaluating their cities and to

\footnotetext{
${ }^{1}$ Present address: N.1 Zhiyinghu Avenue, Caidian District, Wuhan, Hubei, China, 430100
} 
help them to decide what actions to take and not to take (Devuyst et al., 2001). In this context, the main functions of sustainability assessment include decision-making and decision management, target setting, advocacy, participation and consensus building (Joss et al., 2012; Parris and Kates, 2003; Pastille Consortium, 2002). The indicators can be broken down into single-unit indices (such as ecological footprint, wellbeing index, emergy) and indicator-based indices. By contrast with single-unit indices, which score the combined performances of a city, indicator-based indices provide disaggregated information and are used to track sector-level factors (Fiala, 2008).

China has been characterised in recent decades by growing enthusiasm for the development of large-scale eco-cities. At the time of writing, there is no consensus on a rigorous definition of what an eco-city is, and in practice the term is used interchangeably alongside other words for sustainable city models such as "sustainable cities", "low carbon cities", "resilient cities", and so forth, despite the underlying conceptual differences that may exist (de Jong et al., 2015). So the term eco-city may encompass a broad range of factors: carbon-neutral and renewable energy supply; a dense urban fabric supported by a public transport system; resource conservation; water and waste reduction and reuse; green buildings; urban renewal; local urban agriculture; decent and affordable housing for all socio-economic and ethnic groups; improved job opportunities; and voluntary change in lifestyle choices.

The Sino-Singaporean Tianjin Eco-City project has been widely discussed since its inception in 2007. Built close to the centre of Tianjin Binhai New Area and the second government-to-government urban project between China and Singapore, Tianjin Eco-City has been designed to leverage Singaporean expertise in "practical", "replicable" and "scalable" city planning and management (de Jong et al. 2013; M.-C. $\mathrm{Hu}$ et al. 2015; Lee et al. 2014; Weiss 2014). In parallel with the making of master plan, a set of indicators - entitled Key Performance Indicators (KPIs) - an umbrella of twenty-two "control" indicators and four "guidance" indicators, was jointly developed by Chinese and Singaporean specialists. The indicators cover major urban sectors such as air, water, transport and energy (Li et al., 2018). Presented as one of the standout features of Tianjin Eco-City and "the first indicators system bespoke to Chinese eco-cities", the KPI system has been extensively discussed in scientific publications and media communication. However, in-depth studies, among which we can cite the report by Caprotti et al. (2015), have focused on the lack of social balance in this primarily upper-middle-class new town project. There has been little attention on the expected environmental performance of Tianjin Eco-City, which seems have been taken for granted. Other papers are content to praise the high-profile bilateral cooperation in the new town development and the KPIs, with little in-depth scientific investigation.

Echoing the enthusiasm for eco-city development in China, there has been intense discussion of sustainable city indicators by both government institutions and urban specialists around the world. Reflecting today's mainstream concern with the promotion of social equity and economic viability, criticisms of the indicator systems have unsurprisingly concentrated on the imbalance between the environmental and socio-economic aspects (Greed, 2012; Medved, 2016). While recognising the 
importance of reinforcing social equity and environmental viability in the construction of sustainable eco-cities, we argue that this overwhelming focus on the socio-economic dimension may obscure the importance of the environmental indicators themselves. First, environmental challenges remain in the forefront of political discourse (Cook et al., 2017; Hao, 2012; Nelson, 2012; Shiuh-Shen, 2013). Second, environmental performance is a precondition for any achievement in the social and economic arenas, as is apparent in the conventional expression "social and economic development that should be environmentally sustainable".

Given the inherent importance of this environmental dimension of sustainability, governments and non-governmental organisations are keen to devise indicators for the assessment of environmental performance. For instance, the European Union approved the "20-20-20 target" for its environmental agenda towards 2020: a 20 percent reduction in greenhouse gases emissions, a 20 percent share of renewable energy resources and a 20 percent rise in energy efficiency (Moldan et al., 2012). A number of scholars have been calling for environmental indicators to be standardised. In the recent report Tomorrow's City Today, Simon Joss and his collaborators argue for the standardisation of indicators in order to drive innovation and render locally generated knowledge and practice transferable (Joss et al., 2015), following an earlier analysis of the absence of global standardisation of eco-city indicators produced by the same authors (Joss et al. 2012). In the same vein, Shen et al. (2011) point out that the lack of consensus on urban sustainability indicators in local practices has caused confusion in the setting of targets and implementation of policies. A number of governments and non-governmental organisations, such as the World Bank (Suzuki et al., 2010), the United Nations (United Nations, 2007) and Ecocity Builders (2015) have been endeavouring to build overarching systems of sustainability indicators.

Meanwhile, there are impediments to the on-the-ground application of an environmental indicator and substantial questions remain un-answered and in need of elucidation. By way of example, one indicator in the Tianjin Eco-City KPIs refers to the proportion of green trips. Apparently simple and easy to use, this indicator is in fact hard to monitor for multiple reasons. First, there is no consensus at this time on what types of travel (commuting, leisure...) should be included in this category. Second, the geographical range of "green trips" has been defined as the inner part of Tianjin Eco-City, which prompts questions about how the concept of "green trips" is defined in the international literature. For instance, should intercity travel and transit traffic be included in the calculation? Third, the meaning of "green" can sometimes be unclear. How should a vehicle be judged as being green or not? On the basis of vehicle type or power source? Is public transport inherently green? Fourth, what should be the unit of measurement for green trips? Proportion of trips? Cumulative distance? Travel time? This partial list gives an idea of the many questions raised by an apparently simple indicator, which need to be answered before any standardisation can be achieved. While there is no shortage of debate on these conceptual questions, we note that the debates are mostly sectorial, i.e. limited to one indicator or a series of indicators for a given sector, e.g. urban transport.

As previously mentioned, plenty is known about both (Chinese) eco-city development and environmental sustainability indicators, thanks to the work of scientific researchers in recent years. As far as we know, however, there has been no in-depth 
126 study comparing the two, i.e. examining the environmental indicators within the context of a real-world eco-city. Our paper seeks to fill this gap. It takes as its object of study a set of major environmental indicators produced by Tianjin Eco-City, and employs a bibliometric analysis to investigate the scientific rationale behind these indicators. The number of occurrences of each indicator in the international scientific literature was counted, by reference to the following questions: What is the exact definition of a given indicator? What is it supposed to measure? Is the indicator problem-oriented and relevant to the most urgent local concerns? Is it specific to the urban environment? What are the unsolved scientific questions underlying the indicator? Intertwined with these global scientific questions is the question of whether the indicator is specific to the Chinese context or, conversely, context free. Put another way, is the indicator recognised and widely used by researchers inside and outside China? This question will be addressed by geographical analyses of the publications. This will cast light both on whether Tianjin Eco-City's indicators are aligned with mainstream challenges in the field of urban sustainability and on the status of Chinese urban environmental problems in the international research agenda.

The remainder of the article is organised as follows. Section 2 outlines the methodology informing this research, especially the empirical methods used to pick out publications relating to the Tianjin Eco-City KPIs. Section 3 presents the main results of this bibliometric exercise, followed by an overall discussion of the findings and study conclusion in Section 4.

\section{Methodology}

As stated above, our aim is to investigate the scientific rationale behind the environmental indicators used in the Tianjin Eco-City KPIs by analysing the international scientific literature on urban sustainability relating to the indicators in question. To do this, we above all have to construct the corpus of scientific publications that will be the subject of our analysis. However, we encountered methodological hurdles to automatic corpus generation by keyword query, which included the semantic problems caused by the polysemic nature of indicators and the increased blurring of the distinctions between urban and non-urban areas. To overcome these difficulties, we designed a three-step roadmap, which will be described below.

Figure 1 depicts the methodology underpinning this study. Among the twenty-two indicators in the Tianjin Eco-city KPIs, we selected eleven environmental indicators relating to water, air, energy, transport and waste, as listed in Table 1 . The indicator numbers are the same as those published in official documents and research papers, which explains their discontinuity. The Scopus database was chosen for our bibliometric inventory, because it includes publication records for journals since 1996, irrespective of changing ISI status (de Jong et al., 2015). The time span of our collection is from 2000 to 2016 , given that the early 2000s are recognised to be the starting point of urban sustainability policies in China, with the proliferation of eco- 


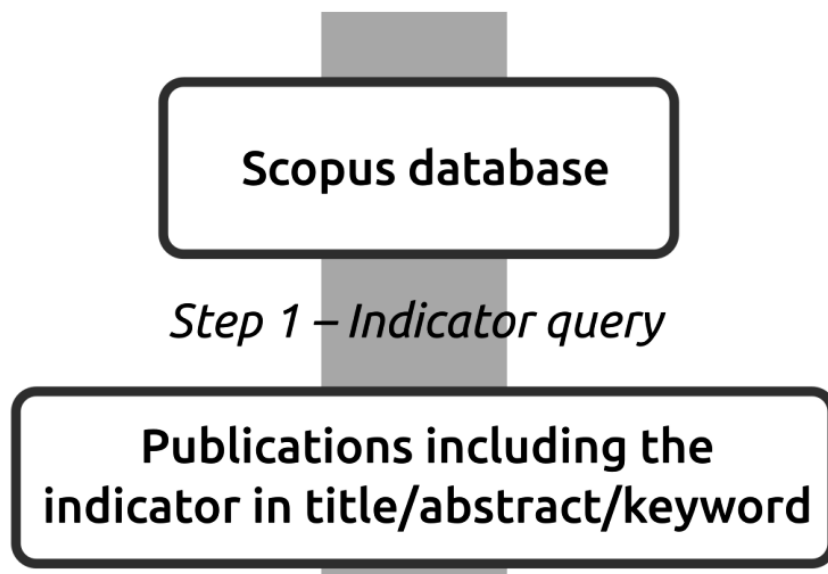

Step 2 - Filtering by urban terms (first-level filter)

Publications including

(a) the indicator and (b) urban terms

Step 3 - Qualitative sorting (second-level filter)

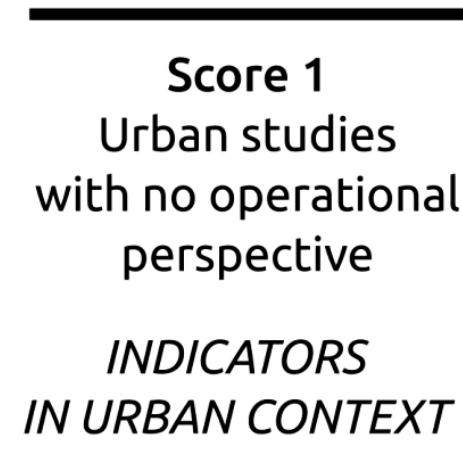

Score 2

Urban studies

dedicated to urban planning and management

INDICATORS

FOR URBAN PLANNING

Figure 1 Research design.

\subsection{Step 1: Indicator query}

171 As indicated above, the study was carried out in three steps. The first was to pick out scientific publications containing references to the indicators through keyword query. The keywords used to query each indicator were constructed through careful interpretation and translation of the official formulation of the indicator. As with many indicators, synonyms and similar expressions can exist and be used in publications at the authors' discretion, so we incorporated all possible variants of the indicators' official formulation into our query. By way of illustration, for the indicator 
Carbon emission per unit GDP, the terms "CO2", "greenhouse gases" and "GHG" are all possible variants of "carbon" and were therefore incorporated into the query. Similarly with "per unit of GDP", for which "per unit of gross domestic product" and "CO2 intensity" were included in the search as possible variants. The detailed syntaxes of the search query are provided in the Appendix.

183 For certain indicators, we judge that the official formulation is not lucid enough and provide further explanations of the definition, as shown in Table 1. These explanations are based on a thorough examination of the guide to the Tianjin Eco-City KPIs published by the eco-city's Administrative Committee, entitled "Navigating the Eco-City" (Tianjin Eco-city, 2010). To give two examples, for the indicator Proportion of green buildings, we explain that the eco-city designed its own standard of green building; for the indicator Overall recycling rate, we give supplementary information on waste categorisation in the eco-city.

191 The result of the query is a corpus of publications for each indicator in which the indicator is referred to in a publication's title, abstract, or keywords.

Table 1 Indicators and targets of the Tianjin Eco-City KPIs selected in the present study.

Supplementary explanation of the indicators is provided when necessary to clarify the definition of the indicator.

\begin{tabular}{|c|c|c|c|}
\hline $\mathrm{N}^{\circ}$ & Indicator & Supplementary explanation & Target \\
\hline \multirow[b]{2}{*}{1} & \multirow{2}{*}{ Ambient air quality } & $\begin{array}{l}\text { Days per year on which ambient air quality } \\
\text { meets Grade II of Chinese National Ambient } \\
\text { Air Quality Standard (GB 3095-1996) }\end{array}$ & 310 days \\
\hline & & $\begin{array}{l}\text { Days per year in which SO2 and NOx content } \\
\text { in the ambient air meets the requirement of } \\
\text { Grade I of Chinese National Ambient Air } \\
\text { Quality Standard (GB 3095-1996) }\end{array}$ & 55 days \\
\hline 2 & $\begin{array}{l}\text { Quality of surface water in } \\
\text { the Eco-city }\end{array}$ & $\begin{array}{l}\text { Surface water quality meets Grade IV of } \\
\text { Chinese National Surface Water Quality } \\
\text { Standard (GB 3838-2002) }\end{array}$ & - \\
\hline 5 & $\begin{array}{l}\text { Carbon emission per unit } \\
\text { GDP }\end{array}$ & - & $\begin{array}{l}\text { t/million US } \\
\text { dollar }\end{array}$ \\
\hline 7 & $\begin{array}{l}\text { Proportion of green } \\
\text { buildings }\end{array}$ & $\begin{array}{l}\text { Tianjin Eco-City's own green building } \\
\text { standard }\end{array}$ & $100 \%$ \\
\hline 10 & $\begin{array}{l}\text { Per capita domestic water } \\
\text { consumption }\end{array}$ & - & 120 l/per/day \\
\hline 11 & $\begin{array}{l}\text { Per capita domestic waste } \\
\text { generation }\end{array}$ & - & $0.8 \mathrm{~kg} / \mathrm{per} /$ day \\
\hline 12 & Proportion of green trips & - & $90 \%$ \\
\hline 13 & Overall recycling rate & $\begin{array}{l}\text { Waste is categorised into domestic waste, } \\
\text { industrial solid waste, construction waste } \\
\text { and other waste. } \\
\text { 'Recycling' includes reuse, recycling and } \\
\text { energy recovery. }\end{array}$ & $60 \%$ \\
\hline
\end{tabular}




\begin{tabular}{|c|c|c|c|}
\hline & & $\begin{array}{l}\text { - There are no separate categories for } \\
\text { hazardous waste from hospitals, industry } \\
\text { and construction }\end{array}$ & \\
\hline 15 & $\begin{array}{l}\text { Treatment to render solid } \\
\text { waste non hazardous }\end{array}$ & - & $100 \%$ \\
\hline 19 & Renewable energy usage & - & $15 \%$ \\
\hline 20 & $\begin{array}{l}\text { Water supply from non- } \\
\text { traditional sources }\end{array}$ & Refers to alternative water resources & \\
\hline
\end{tabular}

\subsection{Step 2: Filtering by "urban" terms}

The second step in the process was to crop the corpus generated by the first step, in order to select urban-related publications by filtering out all studies that are not relevant to urban areas. This was difficult in that urban research is not set as a specific category in Scopus, given that cities are multifaceted and the boundary between urbanised and non-urbanised areas is increasingly blurred (European Commission, 2016). There was therefore no automatic way of filtering out non-urban studies, so one was developed for the present study based on an ad hoc filter on urban terms. To construct the list of urban terms, we used the EuroVoc thesaurus, a multilingual and multi-disciplinary thesaurus which provides a controlled vocabulary set in multiple fields (http://eurovoc.europa.eu/drupal). In the EuroVoc's English language interface, a "construction and town planning" micro thesaurus list is available in the "social questions" domain. The 176 terms included in this list were retrieved and used as our urban filter. It should be noted that the plurals of the terms were also incorporated.

Once the urban filter had been constructed, the abstract, title and keywords of each publication for each indicator were run individually through it. Using the text-mining function in the RapidMiner software (https://rapidminer.com/), the time of occurrence of any word in the urban term list was calculated and numbered. Publications that did not include any urban terms in their title, in their abstract or in their keywords, were considered to be non-urban studies and rejected from the corpus. The outcome of this step was therefore to produce a refined corpus of urban-related studies.

\subsection{Step 3: Unavoidable qualitative sorting}

As described above, the publications rejected by the urban filter can safely be assumed not to be urban-related. Nevertheless, those retained after this step may still not be limited to urban studies, because many words from EuroVoc's "construction and town planning" list, such as "building", "electricity", "community", can also be used in rural settings.

This semantic complication in distinguishing between urban-related and non-urbanrelated studies was bound up with a concern about the paper's subject. For example, should we leave in the corpus relating to water supply from non-traditional sources a publication on techniques for monitoring organic pollutants in sewage treatment plants, given that its abstract does include "water reuse", a term that was included in the search query for the indicator (Robles-Molina et al., 2013)? On the one hand, such 
229 a study can arguably be considered to be urban, given the overlap between the topic 230 and urban sewage and water reuse. On the other hand, it seems somewhat remote 231 from the paper's focus on sustainability indicators for urban planning and 232 management. One possible approach for dealing with such a paper would be to retain 233 it in the corpus but to separate it from those that fully match the focus.

234 At this stage, therefore, we were facing a twofold challenge. First, the non-urban studies that had not been filtered out by the first two automatic steps had to be found and rejected. Second, the urban-related studies had to be classified in terms of their match with our focus. These two tasks entailed a third step, content-based qualitative manual sorting of the publications. In this step, the abstracts of the articles were studied one by one and scored on a 0-1-2 scale, where 0 means totally outside our scope, and 2 highly relevant to our focus on urban planning and management. Particular care was taken when the name of a city was used to provide this study location, as a city name might refer both to the central city area and to the sublevel administrative zones. This is particularly common in China, where a study that refers to Beijing is not necessarily restricted to its inner-city areas but may also include the extensive and still largely rural hinterland.

\subsection{Abstract analysis and geographical analysis}

The total number of 896 publications retained after the three-step query process formed our final corpus, on which an abstract analysis and a geographical analysis were conducted. In the abstract analysis, the abstract of each paper was thoroughly studied, with attention to the following key questions: which indicator is used or mentioned in the study? In which country? Is it the same as the indicator from Tianjin Eco-City? If not, what are its advantages and drawbacks in terms of scientific rationale? This "abstract" analysis was reinforced by a review of the article text in cases where the abstract was too vague to provide any relevant information on the indicator in question.

The purpose of the geographical analysis was to understand how international researchers use the Tianjin Eco-City KPIs. For each article, three pieces of geographical information were retrieved: 1) the country of origin of the authors, i.e. here authors' country; 2) the country studied; and 3) the link between the two. The authors' country, as an aggregate location, quantifies the relative importance of the countries as a source of research. The country studied, also an aggregate location, quantifies the relative interest in a given country as an object of research. The link between the two locations is a piece of relational information that indicates the level of scientific interest in a country A for a country B.A set of text mining methods was employed in order to extract the locations from the corpus. The algorithm was developed under the R software (R Development Core Team, 2011). A set of specific packages were used, mainly stringr (Wickham, 2017) for string manipulation, igraph (Csardi and Nepusz, 2006) and bipartite (Dormann et al., 2009) for network analysis, and ggplot2 (Wickham, 2016) for plotting.

270 Four fields were examined for each study: address of the corresponding author, title,

271 keywords and abstract. The first step was to clean the data (lower case conversion, 
punctuation and removal of editor's location (such as "Copyright Springer Berlin, Germany")). Then, country detection was performed using a dictionary of locations available in the GeoNames database (http://www.geonames.org). We implemented a simple method, applying regular expressions from a list of level-1 administrative units (countries) and some level-2 administrative units. A comparison between the locations retrieved and the results yielded by the Aylien API (http://aylien.com) showed that the simple detection of high-level administrative units would be sufficient to return the location at country level. In most cases the location name is followed by an indication of the country, such as "Muritz National park (Germany)". This indication is missing in a few US and Chinese cases for which only the lowerlevel administrative unit is given, for example "Everglades National Park (Florida)" or "Foshan (Guangdong)".

The time incidence of the country name as the location studied was then calculated both for the entire corpus, expressed as "absolute frequency", and for the corpus of each indicator, expressed as "relative frequency". The difference between the absolute and relative frequency for a country gives the relative weight of the indicator among the eleven indicators regarding that country.

\section{Results}

\subsection{A multi-level final corpus}

Table 2 shows the gradual, step-by-step evolution of the corpus. Figure 2 shows the interplay between the datasets. In total, 8129 publications were generated by the keyword search in step 1. The urban keyword filter in step 2 and the qualitative sorting in step 3 reduced the number of publications to 896, the final number analysed. This corpus is further divided into two categories. The first contains 562 publications, $63 \%$ of the total, which are considered to be specifically linked to the topic of urban planning and management. The remaining $37 \%$ relate to cities and to indicators, but are considered not directly applicable to a city planning and management perspective.

300 There are two main comments to be made on the changes in the number of 301 publications included in the corpuses. First, the indicators examined are common in non-urban studies, which suggests that the indicators are not specific to problems found in urban environments. Second, even when the indicators are associated with urban settings, the objective of the research may in many cases go beyond the dimension of urban planning and management.

Table 2 Quantity of publications generated by each step. It should be noted that the "Urban" column also includes publications that scored 0 in the "Qualitative sorting" column, i.e. which are not urban studies but were not filtered in step 2.

\begin{tabular}{|l|l|l|l|l|l|}
\hline $\mathrm{N}^{\circ}$ & Indicator & Query (step 1) & Urban (step 2) & $\begin{array}{l}\text { Qualitative } \\
\text { sorting } \\
\text { (step 3) }\end{array}$ & $\begin{array}{c}\text { Papers examined } \\
\text { (score 1 and 2) }\end{array}$ \\
\hline
\end{tabular}




\begin{tabular}{|c|c|c|c|c|c|c|}
\hline & & & & Score & number & \\
\hline \multirow{3}{*}{1} & \multirow{3}{*}{ Ambient air quality } & \multirow{3}{*}{350} & \multirow{3}{*}{206} & 2 & 89 & \multirow{3}{*}{142} \\
\hline & & & & 1 & 53 & \\
\hline & & & & 0 & 64 & \\
\hline \multirow{3}{*}{2} & \multirow{3}{*}{$\begin{array}{l}\text { Quality of water } \\
\text { bodies within the } \\
\text { Eco-city }\end{array}$} & \multirow{3}{*}{330} & \multirow{3}{*}{144} & 2 & 88 & \multirow{6}{*}{119} \\
\hline & & & & 1 & 31 & \\
\hline & & & & 0 & 25 & \\
\hline \multirow{3}{*}{5} & \multirow{3}{*}{$\begin{array}{l}\text { Carbon emission per } \\
\text { unit GDP }\end{array}$} & \multirow{3}{*}{505} & \multirow{3}{*}{92} & 2 & 18 & \\
\hline & & & & 1 & 52 & \\
\hline & & & & 0 & 22 & \\
\hline 7 & $\begin{array}{l}\text { Proportion of green } \\
\text { buildings }\end{array}$ & 107 & 33 & & 11 & 30 \\
\hline \multirow{3}{*}{10} & \multirow{3}{*}{$\begin{array}{l}\text { Per capita domestic } \\
\text { water consumption }\end{array}$} & \multirow{3}{*}{58} & \multirow{3}{*}{48} & 2 & 28 & \multirow{3}{*}{36} \\
\hline & & & & 1 & 8 & \\
\hline & & & & 0 & 12 & \\
\hline \multirow{3}{*}{11} & \multirow{3}{*}{$\begin{array}{l}\text { Per capita domestic } \\
\text { waste generation }\end{array}$} & \multirow{3}{*}{46} & \multirow{3}{*}{33} & 2 & 27 & \multirow{3}{*}{27} \\
\hline & & & & 1 & 0 & \\
\hline & & & & 0 & 6 & \\
\hline \multirow{3}{*}{12} & & & & 2 & 89 & \\
\hline & $\begin{array}{l}\text { Proportion of green } \\
\text { trips }\end{array}$ & 231 & 1259 & 1 & 32 & 121 \\
\hline & & & & 0 & 1138 & \\
\hline & & & & 2 & 86 & \\
\hline 13 & $\begin{array}{l}\text { Overall recycling } \\
\text { rate }\end{array}$ & 1584 & 169 & 1 & 37 & 123 \\
\hline & & & & 0 & 46 & \\
\hline & Treatment to render & & & 2 & 21 & \\
\hline 15 & solid waste non & 2155 & 132 & 1 & 30 & 51 \\
\hline & 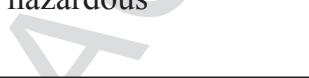 & & & 0 & 81 & \\
\hline & 1 & & & 2 & 67 & \\
\hline 19 & $\begin{array}{l}\text { Renewable energy } \\
\text { ratio }\end{array}$ & 620 & 162 & 1 & 60 & 127 \\
\hline & & & & 0 & 35 & \\
\hline 20 & $\begin{array}{l}\text { Water supply from } \\
\text { non-traditional }\end{array}$ & 62 & 62 & 2 & 30 & 50 \\
\hline
\end{tabular}




\begin{tabular}{|l|l|l|l|l|l|c|}
\hline & sources & & & 1 & 20 & \multirow{2}{*}{} \\
\cline { 1 - 4 } & & & & 0 & 12 & \\
\hline Total & & 8129 & 2340 & - & 2340 & 896 \\
\hline
\end{tabular}

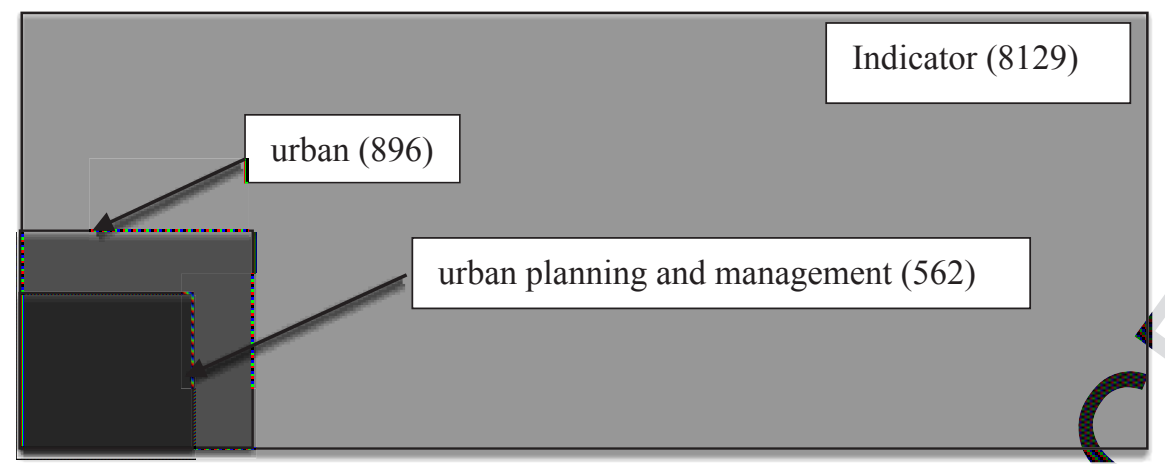

Figure 2 Interplay of the corpuses generated in each step.

\subsection{Authors' countries and studied countries}

310 Figure 3 provides an overview of the links between the authors' countries on the left 311 and the countries studied on the right. The thickness of the line connecting a country 312 A on the left and a country B on the right is proportional to the volume of publications 313 about B produced by authors from $\mathrm{A}$.

314 As can be seen in Figure 3, China and the United States share the first and second 315 positions on the lists of countries studied and authors' countries, respectively. The 316 two countries combined account for $40 \%$ of the cases studied and $42 \%$ of the authors' 317 origins, far ahead of India and the UK, which are respectively in third place on the list 318 of countries studied and on the list of authors' countries. Besides the top four, Japan, 319 Australia, Germany and Spain are well positioned in both lists. Studies relating to the 320 top 10 countries account for $60 \%$ of the total number of publications in the corpus.

321 A dominant share of the studies relating to China are conducted by Chinese authors, 322 the rest being from the US, Australia, Japan, Singapore, UK, Canada, European countries, as well as Hong Kong and Taiwan, which have close links with mainland China. Moreover, the primary research focus of Chinese authors is China, as shown by the multiple links to China on both the left and right sides of Figure 3. American authors, by contrast, have far-flung interests across the world. This is further illustrated by indicator 5 (Figure 7), for which authors from the US publish on 21 countries other than their own, including China. 


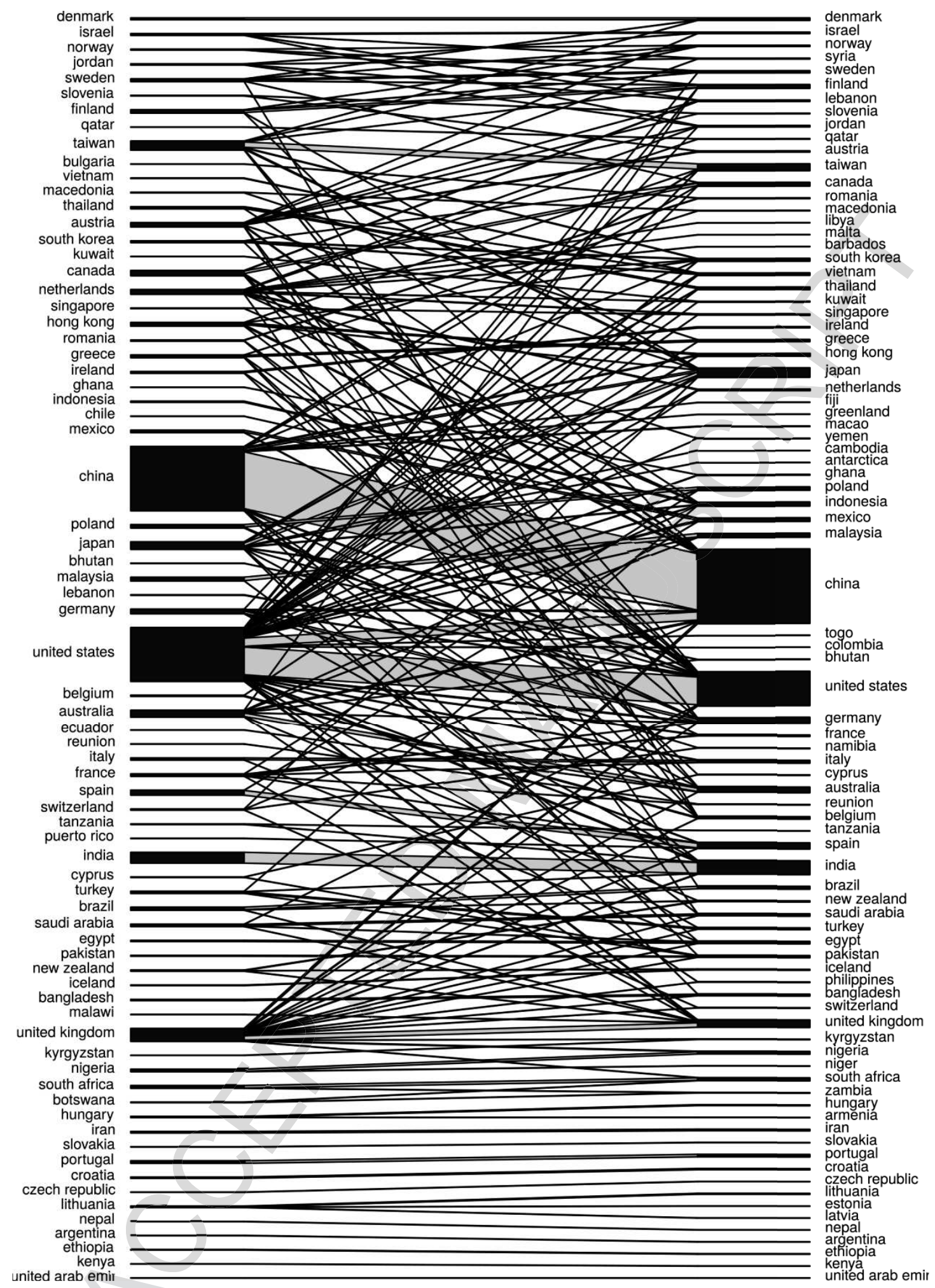

330 Figure 3 Connections between authors' countries and countries studied for the entire indicator 331 set.

332 In order to better understand this overall pattern of connections between authors' 333 countries and countries studied, each indicator's situation was further examined. 334 China and the US are no longer in the first two positions when the focus is shifted to 335 individual indicators. The United States is the country most studied for five out of the 
eleven indicators, including Ambient air quality, Proportion of green buildings, Overall recycling rate, Treatment to render solid waste non hazardous and Water supply from non-traditional sources. China is the country most studied for the other five indicators, including Quality of water bodies, Carbon emission per unit GDP, Per capita domestic water consumption, Proportion of green trips, and Renewable energy ratio.

Details for each indicator are given in Appendix B. Here only the two most relevant indicators - Quality of water bodies and Carbon emission per unit GDP - are discussed. Figure 4 and Figure 5 show the absolute and relative frequencies of the countries studied for indicators 2 and 5 respectively. The absolute frequency of a studied country for an indicator was calculated by dividing the number of occurrences of the country by the total number of publications on this indicator. The relative frequency of a studied country for an indicator was calculated as the difference between the number of occurrences of this indicator for the country and the occurrence of all the indicators combined. The relative frequency of a country reflects the weight of the indicator in the set of indicators concerning the country, and therefore provides at least a partial measure of the relative attractiveness to international scholars of the problems in the sector targeted by the indicator compared with other sectors in the country in question. $78 \%$ of the publications for Quality of surface water (Figure 4) and 42\% for Carbon emission per unit GDP (Figure 5) relate to China. Most of these studies have been conducted by Chinese authors, followed at a considerable distance by American authors (Figure 6 and Figure 7). There are two hypotheses concerning the dominance of Chinese authors for these two indicators. The first is that the perception of surface water quality as an urban concern is a specifically Chinese perspective, rather than one that is widespread elsewhere in the world. Indeed, it is rarely the case that rivers (and to a lesser extent lakes) endure pollution from urban activities alone. The second hypothesis is that the deterioration in surface water quality in China is so serious today that it has become a focus of international research. As to the indicator Carbon emission per unit GDP, the dominance of China as an object of study is more likely attributable to the method of normalisation used. The explanation of this is given in 3.3.2-(2).

The wide-ranging interest of US researchers is clearly shown by Figure 7 for the indicator Carbon emission per unit GDP, where US researchers are observed to have published on 21 countries across the globe besides the United States.

It is interesting to note that China does not appear in the corpus for indicator 15, treatment to render solid waste non-hazardous (the graphic not shown here), a fact that relates to the definition of the indicator. Detailed explanation is given in section 3.3.4. 

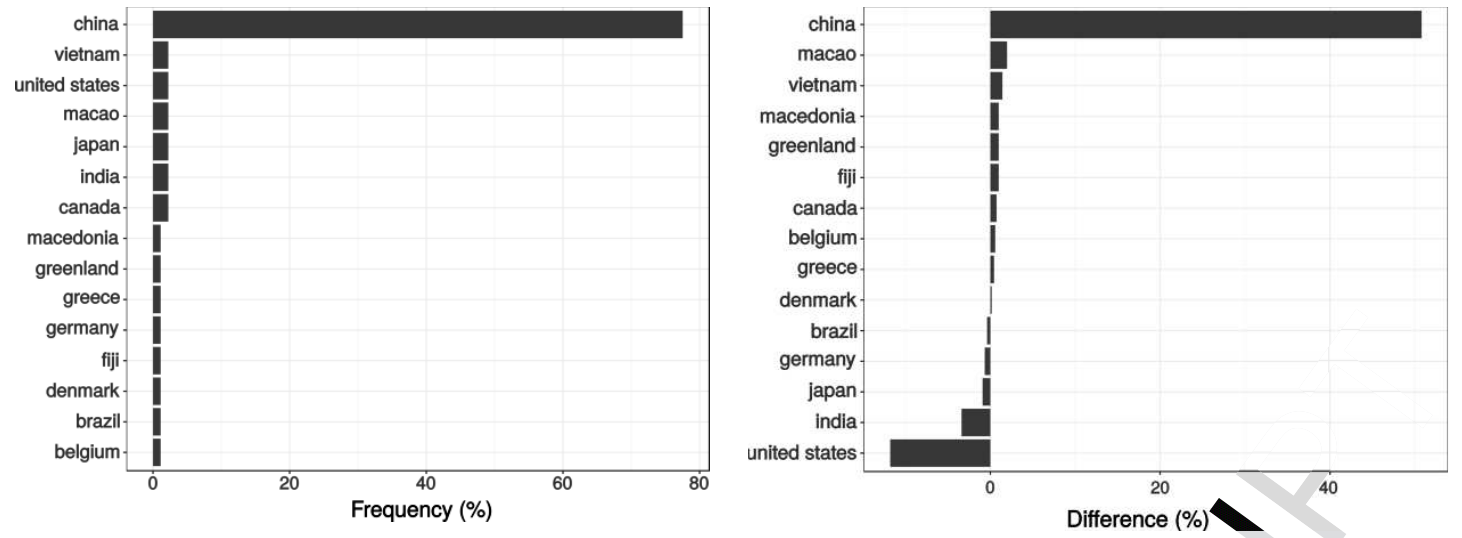

Figure 4 Absolute frequency (left) and relative frequency (right) of countries studied for 375 indicator 2 -- Quality of surface water in the Eco-city.
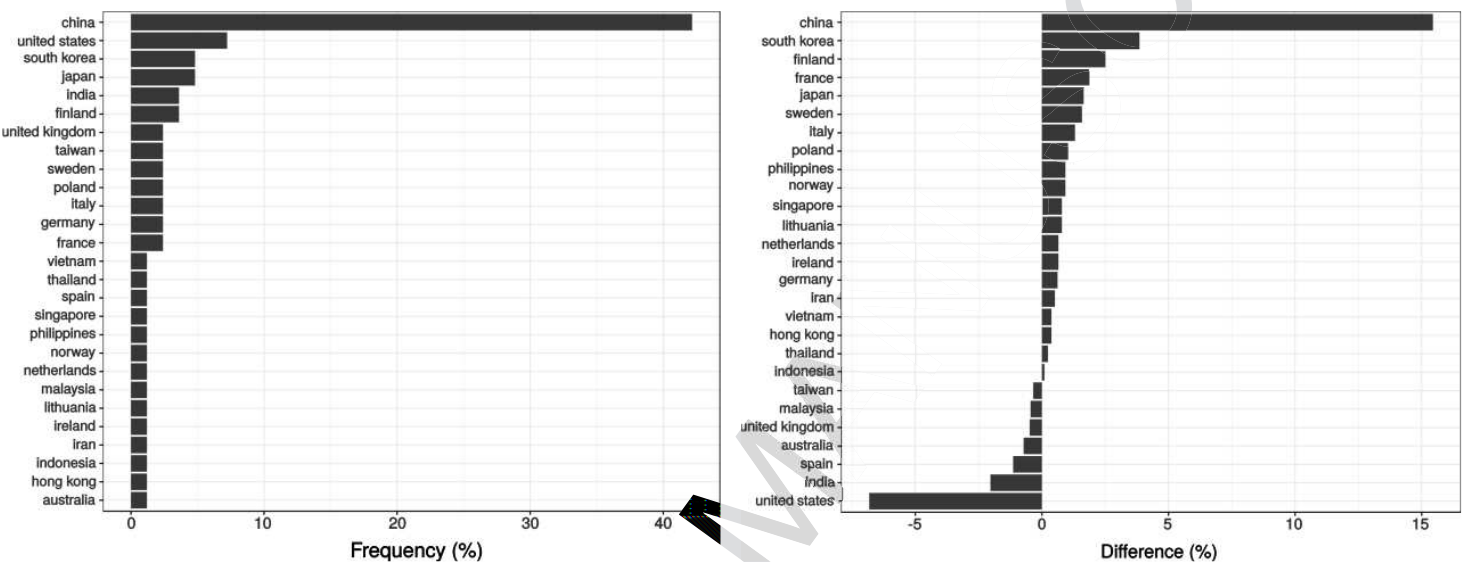

376 Figure 5 Absolute frequency (left) and relative frequency (right) of countries studied for indicator 5 -- Carbon emission per unit GDP. 


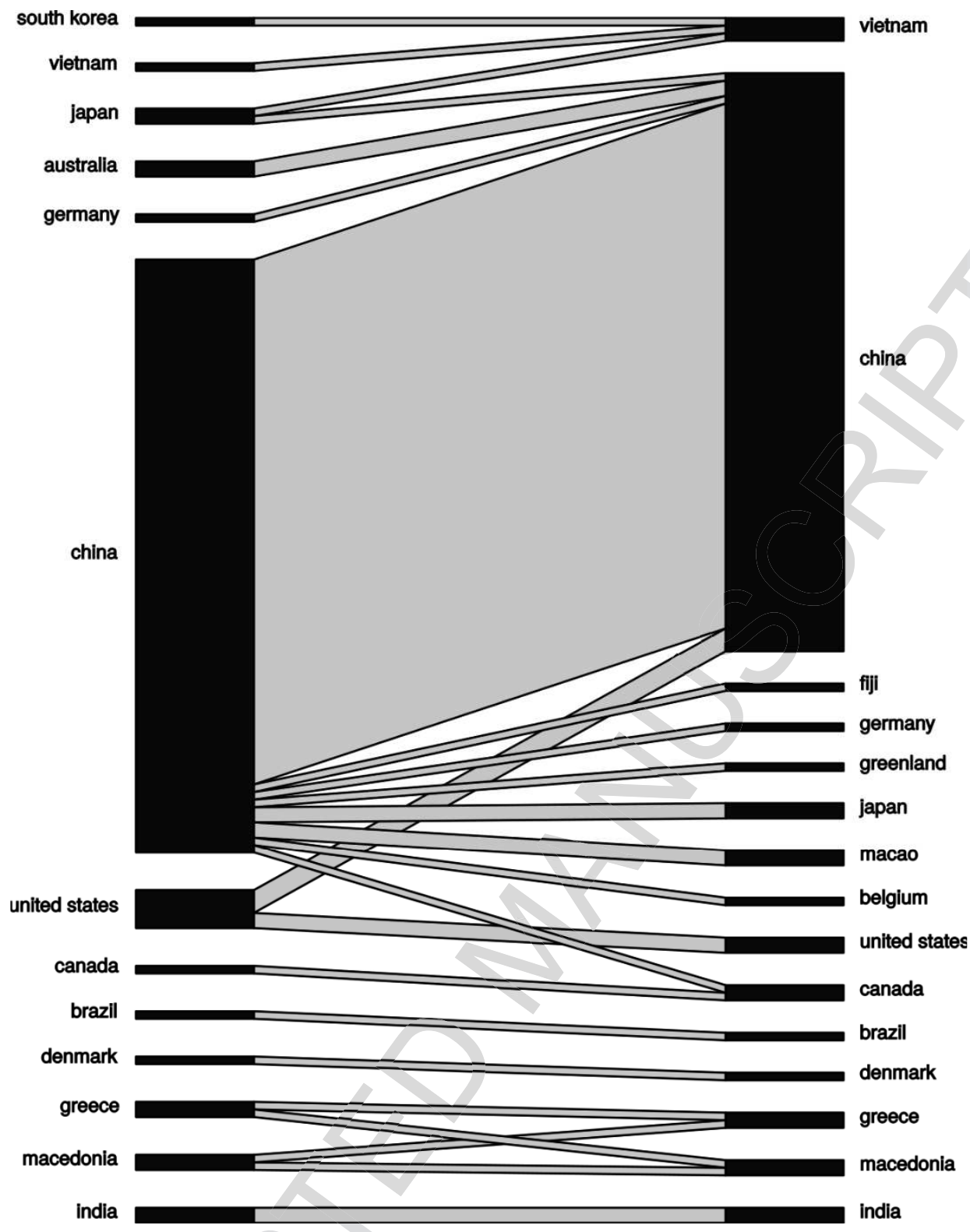

379 Figure 6 Connections between authors' countries and countries studied for indicator 2. 


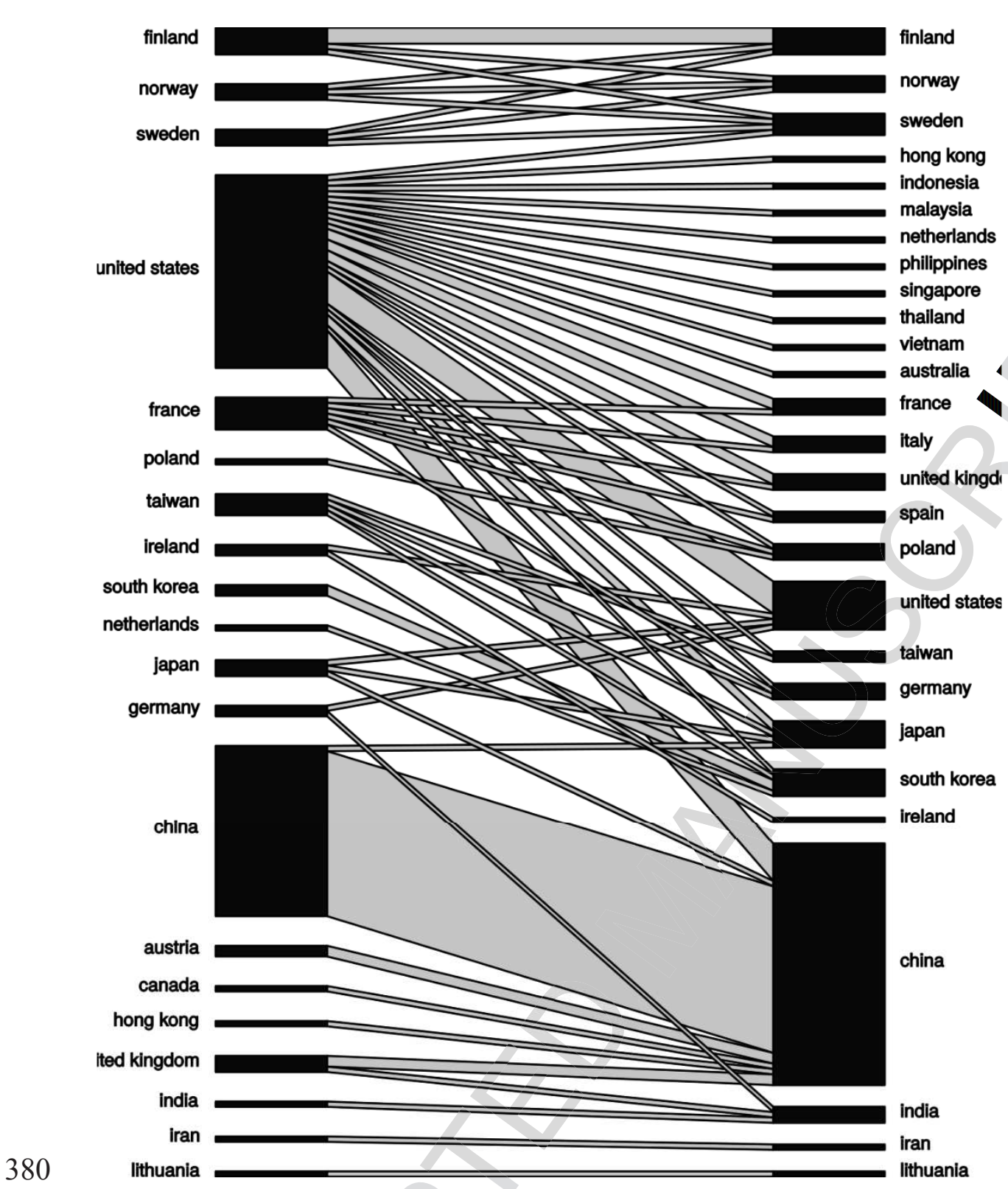

381 Figure 7 Connections between authors' countries and countries studied for indicator 5.

\section{$382 \quad 3.3$ Scientific rationale of the indicators}

383 The eleven environmental indicators are classified into four groups according to their

384 levels of scientific rationale, as discussed below. A detailed note for the scientific 385 rationale of each indicator is provided in Appendix-B.

386 3.3.1 Group 1 Aggregated indicators

387 There are two aggregated indicators among Tianjin Eco-City's environmental 388 indicators, which are Ambient air quality and Quality of surface water. Both 389 indicators are, in fact, a composition of sub-level indices for individual pollutants 390 affecting ambient air quality in the first case and surface water quality in the second 391 case. As can be expected, this type of indicators are made for larger spatial scales and 392 administrative jurisdictions than those of a city - national level in most cases and 393 regional level in the case of the European Union. In the case of a city, such as Tianjin 
394 Eco-City, it is understandable that city managers apply the sectorial standards that have been developed at national level. On this understanding, a comparison was made between the Chinese national standards and the standards from several developed countries in the present study. The current national air quality standard in China, GB3095-2012, is found generally less strict than that of developed countries such as the United States (NAAQS, https://www.epa.gov/criteria-air-pollutants) and the European Union (EU, 2008), which are in their turn less strict than the WHO air quality guidelines (WHO, 2005). For all the criteria pollutants encompassed by these standards, except NO2, GB3095-2012 is more tolerant than the American and European standards. Especially for PM10 coarse particles, the threshold for 24-hour mean concentration defined in the Chinese standard is $150 \mu \mathrm{g} / \mathrm{m} 3$ for residential zones, which is 3 times that of the European and WHO standards, at $50 \mu \mathrm{g} / \mathrm{m} 3$. It can be argued then, achieving the ambient air quality target as defined by this indicator, should it happen sometime in the future, will still fall far short of guaranteeing air quality in the city with respect to public health.

The current Chinese national quality standard for surface water, GB3838-2002, was promulgated in 2002. It is a revised version of the 1983 standard GB3838-83. During the revision, the criterion values were updated, essentially by referencing to the standards of developed countries, including the US, the EU and Japan, given that "there were no lake nutrient criteria related studies during the revision period for GB3838-2002" (Zhou et al., 2014). As a result, the strictness of the criteria values for pollutants in the GB3838-2002 is quite close to that of the developed countries. Certain thresholds in the Chinese standard are even stricter, as noted by $\mathrm{Su}$ et al. (2017). The same authors point out however the lack of contextualisation in the implementation of the standard, stating that GB3838-2002 is "generally applied (in all the lakes) in China without considering the differences in different regions...various climates, elevation, geography and other factors".

It has to be recognized that China needs to consider its economic and social realities (industry-dominant economy, demographic challenge, need of urbanisation...) while making progress in environmental protection. This to some extent explains the lower air pollutant threshold set in the national standard GB3095-2012. Bearing this in mind, the immediate challenge for Chinese environmental protection may not be how to match the standards of developed nations at all costs, but how to develop tailormade indicators that take local specificities into account.

\subsubsection{Group 2 Scientifically-sound indicators}

This category covers the majority of Tianjin Eco-City's environmental indicators, which are:

(1) the two proportion indicators, one pointing to the built sector, proportion of green buildings, the other the transport sector, proportion of green trips;

(2) one of the two energy indicators, renewable energy;

(3) the two indicators of the waste sector, per capita domestic waste generation and overall recycling rate; 
(4) and the two indicators on water consumption, per capita water consumption and water supply from non-traditional sources.

These indicators are clearly defined, measurable, widely known and used across the world for the purposes of sustainability assessment and inter-city comparison. Their main advantage is their concreteness and problem specificity - it is easy to interpret the meaning of the indicator and which problem it targets. Because of this concreteness however, these indicators have relatively limited reach and are little use on their own for assessing holistic performance. For instance, while ratios of renewable energy or green trips can be used to measure the level of deployment of renewable energy and low-emission transport facilities in a city, they cannot measure the city's overall sustainability performance in the energy and transport sectors. Not to mention the technical difficulties of accurately calculating the "ratios", as discussed at the beginning of the paper. Even more bothering, an exclusive focus on these indicators could impede holistic consideration of sustainability -- even at sectorial level -- by overlooking other aspects, such as urban regeneration in the case of green building, water saving in the case of water supply from non-traditional sources, economic viability in the case of renewable energy use, the inclusion of informal collectors in the case of overall recycling rate, and walkability in the case of green trips.

The conciliation between global and local is another critical question raised by the analysis. On the one hand, there are growing calls for the standardisation of sustainability assessment methods and indicators and intensive research efforts made in that direction (Ecocity Builders, 2015; Eurostat, 2016; Suzuki et al., 2010) . On the other hand, the importance of accounting for regional disparities and local characteristics is increasingly recognised, as noted by Joss et al. (2012): "indicators specify in concrete terms what urban sustainability means to a given community by defining the elements and benchmark targets". Taking the built sector for example, whilst the leading certification schemes, namely LEED, BREEAM, CASBEE, and France's HQE, have been widely recognised around the world, their use at local scale is far from systematic. This is undoubtedly attributable to the overwhelming enthusiasm of politicians for economic growth, but also to the fact that these certification schemes are not applicable to local contexts (Zhou et al., 2011). In the case of Tianjin Eco-City, all these well-known foreign green building standards, as well as the Chinese national standards (ESGB and EIASGG), were rejected, giving way to a green building standard developed by the eco-city its own, in order that "local climatic and cultural specificities are taken into consideration during the buildings' performance assessment" (Li et al. 2018).

\subsubsection{Group 3 Indicator under scientific scrutiny}

This group concerns one indicator, carbon emission per unit GDP. The indicator is conventionally used to assess a city's energy performance, together with another form of normalisation for carbon emissions, namely per capita. Despite their widespread use, there is intense debate among scientists over their scientific rationale. 
The problem is twofold. The first concerns the measurement of carbon emissions. How to accurately measure total greenhouse gas (GHG) emissions for a given city, in a global context of increasing interaction between economic activities? Should indirect emissions from local production and consumption be counted in the total GHG? How should emissions relating to import and export activities be counted for? Despite the efforts of scholars to answers these questions (Ala-Mantila et al., 2014; Ramaswami and Chavez, 2013), we seem to be a long way from any universal agreement. The second problem concerns the two possible ways of standardising total emissions, namely per capita or by GDP. Normalising the total emissions of a city by capita or by GDP can lead to contrasting results. For example, Price et al. (2013) reported the carbon emission of two large cities in China, Beijing and Chongqing. Both cities were found to be 20 times more carbon-intensive than international cities when assessed using the GDP-based indicator, but show a similar scale of carbon emissions with the per capita indicator. The authors conclude that indicators of $\mathrm{CO} 2$ emissions per unit of GDP or per capita were too aggregated, and cannot fully explain end-use energy consumption and emissions within a city.

\subsubsection{Group 4 Indicator lacking scientific foundation}

Treatment to render solid waste non-hazardous is the indicator that seems to be the most problematic of the eleven. First, the literal definition of the indicator is confusing. To all appearances this indicator relates to hazardous waste such as electronic or medical waste. In fact however, as explained in "Navigating the EcoCity", the indicator is a portmanteau of multiple waste-treatment goals that basically refer to two fundamental issues in the waste treatment sector. The first is hazardous waste, a term that refers to byproducts of the medical, industrial or construction sectors, and listed in relevant legislative documents promulgated by the Chinese authorities. The second issue concerns the so-called "solid domestic waste", which refers to all the waste generated by urban human activities, with the exception of the three types of hazardous waste mentioned above. Rendering this kind of waste "nonhazardous" means "setting up an appropriate hierarchical disposal system through landfill, biological treatment, recycling, incineration and energy-recover facilities" and "assuring that the emissions from each of these procedures meet the relative national standards". As a whole, the indicator "treatment to render solid waste nonhazardous" means "to proceed to non-harmful disposal of the hazardous waste and solid domestic waste in order that the harmful substances contained in these wastes meet the current national or sectorial pollutant discharge standard" (Tianjin Ecocity, 2010). The value of the indicator will be a calculation of the ratio between the quantity of hazardous/solid waste that has been rendered "non-hazardous" and the total quantity of such waste generated in the eco-city before disposal.

Having clarified the definition of the indicator, we can now fairly safely argue that the indicator should be replaced by one or more indicators that will be simpler, more concrete and more problem-focused, in a nutshell, more scientifically sound. It would be interesting to know why the indicator has been formulated in this way, but that is beyond the scope of this paper. Here we will be content to note that the United 
521 Nations sets separate guidelines for the indicators on "waste treatment and disposal"

522 and "generation of hazardous waste" (United Nations, 2007).

\section{Discussion and conclusion}

524 In this paper, we have conducted a comprehensive bibliometric investigation into the scientific rationale for the environmental indicators used in the Tianjin Eco-City KPI system. To our knowledge, this is the first time that the well-known Tianjin Eco-City KPIs have been scientifically studied, and also the first time that a set of real-case environmental sustainability indicators has been addressed as a whole.

529 The results reveal above all that the Tianjin Eco-City KPIs are far from being a 530 system specifically dedicated to the urban scale, but are applicable to a city, to a 531 region, or to a country. This is in fact not so surprising if two realities are recognised: 532 1) that the boundaries between urban and rural are increasingly blurred, both 533 conceptually and in practice; and consequently 2) that no one can tell today how urban sustainability might differ from sustainability in general. There are actions and programmes dedicated to both themes, but the difference between urban and nonurban sustainability is never specifically discussed and the formulation is more likely to be case-specific (urban sustainability when the case studied is a city and sustainability otherwise) than to be based on a scientific rationale. Suffice it to say that applying nationwide sustainability indicators to a city without contextual adaptation could lead to inappropriate measures and unwanted consequences. In the case of Tianjin Eco-City, the course of the river within the jurisdiction of the Administrative Committee has been artificially cut off from the polluted river upstream, so that surface water quality inside the city meets the requirements of the indicator (Li et al., 2018), a pragmatic measure that can safely be described as unsustainable.

546 That having been said, most of the environmental indicators from Tianjin Eco-City are found to be scientifically relevant, which means that they are clearly defined, problem-oriented, measurable and widely used by the international community involved in urban sustainability. This is the case, for example, of per capita domestic water consumption and renewable energy ratio. Nonetheless, there is still the challenge of how to standardise measurement/calculation of the indicator and how to gear considerations towards holistic urban sustainability by avoiding excessive attention to one facet at the expense of the others.

554 As for the two indicators taken from the national standards on ambient air quality and surface water quality, the question concerns the rationality of applying the national scale indicators to city-level management. Clearly, the eco-city's managers can do little about upstream water pollution outside the city (except through drastic measures such as cutting the water course), or about air pollution originating from other parts of Tianjin and north China. In other words, meeting air and water quality targets depends less on measures taken inside the eco-city than regional and national policies. In consequence, the relevance of setting such indicators at eco-city scale, though politically acceptable and necessary, is questionable. 
563 The differences in the scientific rationale for Tianjin Eco-City's environmental 564 indicators are further reflected in their dispersal across the international scientific 565 literature, as revealed by our geographical analyses. The connections between the 566 authors' country and the country studied for the whole set of indicators clearly 567 confirm that China remains the hotspot of world research on environmental 568 sustainability, and that the Western world (US, Europe, Japan, etc.), to which China has turned for finding new planning strategies and technical environmental solutions during the recent decades, maintain their interests in China's urban and ecological transition. Furthermore, the eco-city's environmental indicators, at least the main ones that have been selected in this study, are consistent with the major challenges in making sustainable cities that have been recognised by international scientists: urban air pollution, clean energy use, traffic congestion, $\mathrm{CO} 2$ emissions, water saving and reuse, waste reduction, etc. These challenges are a matter of debate in a wide range of countries across the world, as shown by our geographical analysis. Two of the eleven indicators are found to be very "Chinese", namely Quality of water bodies and Carbon emission per unit GDP, for which papers about China account for $78 \%$ and $42 \%$ of the corpus, respectively. Since the possible reasons of this have already been developed, here we will focus on two important issues revealed by these indicators:

- Should trans-boundary pollution, such as that of a river, be defined as the responsibility of a city and incorporated into the assessment of the city's sustainability performance? While the answer is a priori negative, in a country like China where administration is highly segmented, strictly top-down, and framework for watershed management has yet to be built, it seems difficult to see other ways to tackle the watercourse pollution problem that has already become critical.

- Bundling environmental performance with economic outcome, as embodied by the indicator Carbon emission per unit GDP, to some extent reflects the tricky choice between economic growth and environmental protection in Chinese cities, at a time when a balance between economic and environmental objectives remains to be found, whether in China or elsewhere. Still, measuring pollution in relation to GDP is fraught with risk as it presupposes that "you can continue to pollute if it creates enough growth".

- The nature of existing indicators should be defined if these indicators are to be recycled in a new system. Local conditions and the characteristics of the (eco-city) project are main factors that impact the suitability of the indicators in the specific setting. In case where an indicator is an aggregated one or/and has been made for national- or regional-scale management, such as those used for air quality and water quality in Tianjin Eco-city, the applicability of the indicator in the new setting should be considered with caution.

- The exact definition of an indicator should be clearly understood, and its scientific rational sufficiently evaluated. An indicator is a highly synthetical 
thus simplified expression of sustainability goals, and this simplicity could easily lead to inexact even incorrect interpretation of the goals. Exact understanding of the meaning of the indicator is a pre-condition for evaluating its scientific rational, which in its turn impact the utility and exportability of the indicator.

- Last but not least, an indicator system embodies its makers' understanding of and preference to sustainability, thus its nature and scientific rational can be conditioned by the makers' specialty. It is thus of importance to investigate the construction process of an indicator system - who made the indicators, how were the indicators selected - before taking the system as a reference.

The scientific contribution of this paper is three-fold. First, it is the first time that the Key Performance Indicators of Tianjin Eco-City is analysed, with a focus on their scientific rationale. To our knowledge, it is also the first time that a set of urban environmental indicators is analysed about scientific rationale. Second, instead of higher-level social-economic reflections, we deal with the most basic one among the three pillars of sustainability, environment, in which field problems are far from being solved, especially in rapidly urbanised countries like China. We suggest environment performance of our cities remain an issue to be tackled and should not be overlooked. Third, we show a picture of the consilience and contrast between Chinese perception of urban environment performance and international ones. The information revealed is expected inspirational both for Chinese and international specialists in sustainability.

Finally, our work has limitations. The most significant is perhaps the source used for the bibliometric survey. We used bibliometric tools to sample the most relevant academic publications in Scopus that contain environmental indicators that overlap with the Tianjin Eco-City KPIs. However, urban development and sustainability are core concerns not only for academics, but also for policymakers, practitioners, consultants, think tanks, environmental industries, non-governmental organisations, economists, the media... Writings produced by these actors, such as reports, policy documents and technical manuals, may not be published in scientific journals.

\section{Acknowledgements}

This study was supported by France's Agence Nationale de la Recherche through the investissement d'avenir - Labex Urban Futures funding programme and by École des Ponts ParisTech. We would also like to thank Martin de Jong from Delft University of Technology for his helpful comments on an earlier version of the manuscript. 


\section{Appendix}

A. Keyword query per indicator

643 Table 3 Search terms employed and the number of publications found in each step.

\begin{tabular}{|c|c|c|}
\hline $\mathrm{N}^{\circ}$ & Indicator & Query in Scopus \\
\hline 1 & Ambient air quality & $\begin{array}{l}\text { TITLE-ABS-KEY ( "Ambient Air Quality" AND "days" ) AND PUBYEAR } \\
>1999\end{array}$ \\
\hline 2 & $\begin{array}{l}\text { Quality of water bodies } \\
\text { within the Eco-city }\end{array}$ & $\begin{array}{l}\text { ( TITLE-ABS ( "surface water" W/2 "quality Standard" ) ) OR ( TITLE- } \\
\text { ABS-KEY ( "Quality Standards for Surface Water" OR "surface water } \\
\text { environmental quality standards" OR "standard of Environmental Quality } \\
\text { Standards for Surface Water" OR "surface water environment quality } \\
\text { standard" OR "surface water quality standards" OR "water quality standards } \\
\text { for surface water" ) ) AND PUBYEAR > } 1999\end{array}$ \\
\hline 3 & $\begin{array}{l}\text { Carbon emission per } \\
\text { unit GDP }\end{array}$ & $\begin{array}{l}\text { (TITLE-ABS-KEY ( ( ( carbon OR "CO2" OR "greenhouse gas" OR } \\
\text { "GHG") W/2 emission ) AND ( "per unit of GDP" OR "per unit GDP" OR } \\
\text { "per GDP indicator" OR "per unit of gross domestic product" ) ) OR "CO2 } \\
\text { intensity" OR ( "tons of carbon equivalent" AND ( gdp OR "gross domestic } \\
\text { product" ) ) ) AND PUBYEAR > } 1999\end{array}$ \\
\hline 4 & $\begin{array}{l}\text { Proportion of green } \\
\text { buildings }\end{array}$ & $\begin{array}{l}\text { TITLE-ABS-KEY (("Sustainable buildings" OR "Green Buildings" OR } \\
\text { "High-performance buildings" OR "eco construction" OR "ecoconstruction" } \\
\text { OR "sustainable construction" OR "green construction" OR "eco architecture } \\
\text { " OR "eco architecture " OR "sustainable architecture " OR "green } \\
\text { architecture") W/1 (proportion OR rate OR ratio OR percentage)) AND } \\
\text { PUBYEAR > } 1999\end{array}$ \\
\hline 5 & $\begin{array}{l}\text { Per capita domestic } \\
\text { water consumption }\end{array}$ & $\begin{array}{l}\text { TITLE-ABS-KEY ( ( "domestic water consumption" OR "Household water } \\
\text { consumption" OR "Residential Water consumption" OR "water consumption } \\
\text { of Household" ) AND ( "per capita" OR "per person" OR "per habitant" OR } \\
\text { "per citizen" OR "per resident" OR "per inhabitant" ) ) AND PUBYEAR > } \\
1999\end{array}$ \\
\hline 6 & $\begin{array}{l}\text { Per capita domest } \\
\text { waste generation }\end{array}$ & $\begin{array}{l}\text { TITLE-ABS-KEY ( ( ( ( "waste generation" OR "waste production" OR } \\
\text { "generation of waste" ) W/3 domestic ) OR "domestic waste" ) AND ( "per } \\
\text { capita" OR "per person" ) AND ( "kg" OR kilogram OR ton ) ) AND } \\
\text { PUBYEAR > } 1999\end{array}$ \\
\hline 7 & Proportion of green trips & $\begin{array}{l}\text { TITLE-ABS-KEY ( "low carbon transportation" OR "low carbon transport" } \\
\text { OR "green trip" OR "green transport" OR "green transportation" OR } \\
\text { "sustainable transportation" OR "sustainable transport" OR "eco mobility" } \\
\text { OR "ecomobility" ) AND PUBYEAR > } 1999\end{array}$ \\
\hline 8 & Overall recycling rate & $\begin{array}{l}\text { TITLE-ABS-KEY ( ( "recycling rate" OR "recycling ratio" OR "recycling } \\
\text { performance" ) ) AND PUBYEAR > } 1999\end{array}$ \\
\hline 9 & $\begin{array}{l}\text { Treatment to render } \\
\text { solid waste }\end{array}$ & $\begin{array}{l}\text { ( TITLE-ABS-KEY ((nonhazardous OR ( toxic W/1 non ) OR ( hazardous } \\
\text { W/1 non )) AND (waste AND NOT wastewater)) AND PUBYEAR > 1999) }\end{array}$ \\
\hline
\end{tabular}




\begin{tabular}{|c|c|c|}
\hline & nonhazardous & \\
\hline 10 & $\begin{array}{l}\text { Renewable energy } \\
\text { usage }\end{array}$ & $\begin{array}{l}\text { ( TITLE-ABS-KEY ( "Renewable energy usage" OR "Renewable energy } \\
\text { utilization" OR "Renewable energy use" ) ) AND PUBYEAR > } 1999\end{array}$ \\
\hline 11 & $\begin{array}{l}\text { Water supply from } \\
\text { nontraditional sources }\end{array}$ & $\begin{array}{l}\text { TITLE-ABS-KEY ( ( urban OR city OR town ) AND ( "water reuse" OR } \\
\text { "rain water harvesting" OR ( water AND "non-traditional sources" ) OR } \\
\text { "non-traditional water sources" OR ( water AND "alternate sources" ) OR ( } \\
\text { water AND "alternative sources" ) OR "alternate water sources" ) AND ( } \\
\text { "per capita" OR "per person" OR "per inhabitant" OR "m3/d" OR "gal" OR } \\
\text { "litre" OR "liter" OR "m/day" OR proportion OR percentage )) AND } \\
\text { PUBYEAR > } 1999\end{array}$ \\
\hline
\end{tabular}

\section{B. Notes per indicator on the scientific rationale}

646

\section{B.1 Indic 1 Ambient air quality}

Clean air is recognised as a basic requirement of human health and well-being. The primary factors of ambient air quality include land use, traffic emissions, industrial emissions, biomass burning and trans-border air movement (Ling et al., 2010). Many countries have set their own air quality standards. The most frequently cited standard is the US Environmental Protection Agency's National Ambient Air Quality Standards (NAAQS). Of the 144 studies scored 1 or 2, 50 use the NAAQS, of which 9 are about areas outside the Unites States. The second mostly used standard is the Chinese Ambient Air Quality Standards (GB3095-2012), with 20 occurrences, followed by the Indian National Ambient Air Quality Standards, 14 occurrences. The European Union Air Quality Standard (EU, 2008) is commonly applied in European Member States. The World Health Organisation guidelines (WHO, 2005), which set lower guideline values for air pollutants than those of national standards, is only referred to in 4 of the 144 studies.

Few studies address the relevance of the standards themselves. Among them, Tao et al. (2015) monitored air quality and hazy weather conditions on an urban site in Guangzhou, and found that the incidence of hazy weather was not reduced as much as expected, because of humidity. The authors therefore suggested more stringent PM2.5 guideline values in the national standard, with a distinction between dry and wet conditions. J. Hu et al. (2015) found that the current Chinese air quality index based on the maximum value of individual pollutants underestimated the severity of the health risk associated with air pollution caused by multiple pollutants.

As to the metrics of air quality, maximum daytime hourly value is probably the most representative indicator, because the daytime concentration profile of the pollutants is influenced by meteorological drivers and anthropogenic activities. In Chinese cities, except for ozone (Shan et al., 2008), there is a priori not distinction between weekdays and weekend ( $\mathrm{Hu}$ et al., 2014), probably because of the relatively homogeneous patterns of urban activity within Chinese cities across the week. Andrews (2008) was the sole author who questioned the current air quality metrics used in China. By analysing the discrepancy between reported 'Blue sky' days in Beijing and published monitoring station data for the period 2002-2007, the author 
observed that the reported improvements in air quality were more attributable to deficiencies in the metrics than to tangible air quality improvement.

\section{B.2Indic 2 Quality of surface water in the eco-city}

The first finding for this indicator is that Chinese studies, i.e. both the authors and case study are Chinese, represent a majority of the corpus. Nevertheless, of the 119 papers retained, no one investigates urban water quality from a planning perspective. The studies focus mostly on surface water sampling and chemical analysis of the water quality. This finding has two implications. The first is the cross-boundary nature of the water quality deterioration, of which contributors go beyond urban activities. For example, intensive use of pesticides in rural areas is a main contributor to water body deterioration. Second, the quality of watercourses should be managed by basin and not by administrative jurisdictions. Integrated river basin water management (IRBM) is governance approach of surface water in Europe (EU, 2008). China is also on its way to setting up its own IRBM systems (NPC, 2002). Clearly then, surface water quality goes beyond the scope of city planners and managers.

The current National Environmental Quality Standard for Surface Water in China, GB3838-2002, promulgated in 2002, is the third revision of the 1983 standard GB3838-83. In GB3838-2002, the guideline values were mostly set in reference to the standards of certain developed countries (US, EU and Japan), in a context where " (there was) not lake nutrient criteria related studies during the revision period for GB3838-2002" (Zhou et al., 2014). Therefore, the stringency of the guideline values set in the Chinese standard is similar to, and sometimes even more stringent than that from other countries. However, there seems a lack of consideration of local conditions when the guideline values were chosen. Chinese authors Su et al. (2017) acknowledged the findings of Ding et al. (2015) and noted that GB3838-2002 is "generally applied (in all the lakes) in China without considering the differences in different regions...various climates, elevation, geography and other factors". Besides, Ma et al. (2015) indicate that the current water quality identification indices in the GB3838-2002 do not consider the degree of importance of each parameter.

\section{B.3 Indic 5 Carbon emission per unit GDP}

Only 69 out of 505 search-generated articles (step 1 and 2) are urban studies, which indicates that greenhouse gas (GHG) emissions is a concern that crosses the boundary between urban and rural. The examination of the articles' abstracts reveals that the development of scientifically sound approaches of emission assessment remains a topic of debate. Scholars disagree on a multiple of issues, as described below.

\section{1) GHG emissions calculation}

Numerous questions about how to accurately calculate total GHG emissions for a given country or city remain unsolved. These include: Should indirect emissions from local production and consumption be left out of total GHG emissions? Should GHG from infrastructures and local community consumption be included? How do you account for emissions associated with import and export? Despite of the efforts made 
717 by many researchers on questions (Ala-Mantila et al., 2014; Ramaswami and Chavez,

718 2013), there seems to be a long way to go before any universal agreement be found.

719 2) Normalisation

720 Indicators of GHG intensity build generally on a normalisation by GDP - this is the 721 case for Tianjin Eco-City - or per capita. Depending on specific conditions, these two 722 normalisations methods may lead to contradictory results. In a comparative study 723 conducted by Price et al. (2013), for instance, the two Chinese cities studied, Beijing 724 and Chongqing, were found to be 20 times more carbon intensive than international 725 cities as calculated by the GDP-based indicator, while they manifested similar scales 726 of carbon emissions according to the capita-based indicator. The authors argued 727 furthermore that indicators of $\mathrm{CO} 2$ emissions per unit of GDP or per capita were too 728 aggregated and could not fully explain end-use energy consumption and emissions in 729 a given city. They developed therefore a composite end-use low-carbon indicator that 730 took into account, for a given city or country, both the normalised per-sector energy 731 consumption and the percentage contributions of the end-use sectors to total local 732 energy use.

\section{3) Energy consumption and GHG emissions}

734 Last but not least, energy consumption and GHG emissions should be distinguished 735 even though they are closely connected. Between them lies a hidden variable - carbon 736 intensity in energy supply - which expresses the amount of carbon emitted per unit of 737 energy and depends on the energy fuel mix (Ramaswami and Chavez, 2013). In 738 concrete terms, a decline in a city's GHG emissions does not necessarily imply better 739 energy-saving policies, since it can be a consequence of, say, a global shift from coal 740 to renewable energy in national energy production.

The quantity and diversity of green building rating systems around the world is increasing. The current frontrunners include LEED (USA), BREEAM (UK), CASBEE (Japan) and, to a lesser degree, France's HQE. In China, two standards coexist, which are, ESGB promulgated by the Ministry of Construction, and EIASGG by the Ministry of Environment. Their on-ground implementation is, however, not for granted. A convincing example is Tianjin Eco-City, which has established its own green building standard. in order that "local climatic and cultural specificities are taken into consideration during the buildings' performance assessment" (Li et al. 2018). Vij (2010) advocated for developing countries to produce their own assessment and rating tools which cater to their 'specific concerns and factors in the local building industry and construction standards'.

In broad terms, the proportion of green buildings is an indicator frequently used to appraise sustainability. Paradoxically, however, it is not easy to find rankings of cities or countries based on the proportion of green buildings. According to a report by Mohan and Loeffert (2011), approximately 5\% of buildings in the United States were 757 LEED certified green buildings as of 2011. 
758 Buildings have been recognised as major consumers of energy and emitters of

759 greenhouse gas, so it is understandable that the quantity of green buildings in a city

760 represents to a certain level its performance as regard to sustainability. As

761 certification schemes for green buildings have become increasingly popular, it seems

762 crucial today to clarify how these international and local schemes differ from one

763 another. All of them undoubtedly cover factors such as energy efficiency, reduced

764 carbon emissions, rainwater recycling and reuse, etc. What is interesting to know is

765 how the indicators for the same factor are differently defined in different certification

766 systems. More importantly, constructing green buildings should not be a goal in itself,

767 but a way of achieving tangible sustainability outcomes. The undue enthusiasm for 768 green building labelling and for the construction of new buildings to be labelled can

769 blind us to the importance of renovating existing buildings. As Onat et al. (2014)

770 remarked, 'focusing on the construction rate of net zero or high performance green

771 buildings alone did not help with stabilising or reducing GHG emissions unless the

772 retrofitting of existing residential building stock was seriously considered as a strict

773 policy along with green building policies'. Should a city district that consists

774 exclusively of new green buildings with old buildings entirely demolished be

775 considered more sustainable than a district where old buildings have been preserved

776 and retrofitted but without being able to be labelled as green buildings?

777 B.5 Indic 10 Per capita domestic water consumption

778 Residential water consumption is an essential field of urban planning (Troy and 779 Holloway, 2004). Our review shows that per capita consumption is the indicator 780 commonly used to measure domestic water demand and to plan water supply.

781 Water demand is expected to increase in coming years as a result of climate change, 782 especially in arid and semi-arid regions (Yan, 2013). Rain water harvesting and water 783 reuse offer two major water supply alternatives. While it is obvious that reuse policies 784 can save large quantities of water from potable sources (Gonzalez et al. 2011), public 785 perception has proved to be a big challenge to the implementation of such policies. It 786 has been found that the public tends to be more supportive of low-contact reuse, less 787 so for higher-contact reuse (Friedler and Lahav, 2006; Matos et al., 2013). It is thus 788 recommended to use holistic tools, which assess not only technological and 789 environmental benefits but also socio-cultural, institutional and economic factors 790 when water reuse is planned (Garcia et al., 2015; Rahman et al., 2010; Urkiaga et al., 791 2008). Furthermore, the question of alternating water sources should be considered 792 within a broader category of urban water management (Capodaglio et al., 2016).

793 With regard to technological possibilities contributing to better management of urban 794 water demand, automated water meters are proved to be efficient appliances because 795 of their monitoring capacity. The installation of such equipment can lead to an 796 immediate reduction in water use (Harutyunyan 2012; Joo et al. 2015).

797 While there are growing international calls for water conservation, current pricing 798 policies for this fundamental and inelastic need are seemingly inconsistent with the 799 international consensus (Salman et al., 2008). A survey in the city of Qingdao, China, 800 shows that the average proportion of household expenditure on water is no more than 
0.40\% (Jin et al., 2015). Harutyunyan (2012) found that water consumption would rebound after a short, though sharp decline following the installation of water meters, if water prices were not adjusted at the same time. Similar finding have been reported by Fielding et al. (2013).

There seems to be a need for technological improvement in household appliances in order to avoid waste. In the UK, $10 \%$ of daily per capita household water consumption is caused by waiting for tap water to become hot (Nawaz and Waya, 2014). Separate indicators for cold and hot water consumption might provide a better guide to action than aggregated per capita water consumption.

\section{B.6Indic 11 Per capita domestic waste generation}

Per capita per day is a conventionally used norm for measuring the rate of urban waste generation, alongside its two alternatives, per week or per year. The lack of international standards and methodologies for characterising urban solid waste is recognised to be problematic: the content of reported waste may vary from one city to another, making intra-city comparisons difficult (Edjabou et al., 2015). An example of this concerns Chinese cities. While one study reported a waste generation rate of $1.08 \mathrm{~kg} /$ person/day in Chongqing (Hui et al., 2006), another study showed a very low rate of $0.23 \mathrm{~kg} /$ person/day in Beijing (Qu et al., 2009). The stark contrast between the two Chinese megacities is less likely a reality than an artefact of possible differences in the method of measurement.

Of equal importance are the manner and the extent to which socio-economic conditions influence waste generation. Findings on this issue diverge. Gomez et al. (2008), Sujauddin et al. (2008) and Ogwueleka (2013) found positive correlation between household income and per capita waste generation, whereas Phuntsho et al. (2010) reported an absence of 'conclusive result' between the two. Qu et al. (2009) even found negative correlation between household size/income and waste generation. In general terms however, economic and policy incentives such as 'payas-you-throw', and spending on education, are found to be effective measures for reducing waste generation (Grazhdani, 2016).

\section{B.7Indic 12 Proportion of green trips}

Sustainable transport is a pre-requisite for a sustainable city (Wadhwa, 2000). To date, however, there is no generally accepted definition of sustainable transport, or its variant, "green trips" used in Tianjin Eco-City. Indeed, indicator occupies a core position among urban transport studies (Buzási and Csete, 2015). Baggen and Aben (2006) suggest using time, price and comfort as criterion to compare the performance of urban transport solutions. Jiang et al. (2013) developed a system of 26 indicators to measure transport sustainability in Chinese cities. Among the indicators, "public transport and non-motor share (\%)" is similar with Tianjin Eco-City's green trips indicator.

Developing a transit network that offers a variety of transport options and favouring walkability is the primary policy for city sustainability (Haghshenas et al., 2015; Wey and Hsu, 2014). Assessing the performance of a city's transport system is an 
843

844

845

846

847

848

849

850

851

852

853

854

855

856

857

858

859

860

861

862

863

864

865

866

867

868

869

870

871

872

873

874

875

876

877

878

879

880

881

882

883

884

885

extremely complex task, bound up with issues such as renewable energy use, GHG emissions, and socio-economic reliability. As Kasperska (2015) says, "How to minimise the costs generated by the development of innovative transport infrastructures and offset them by environmental and social gains is still a challenge". In light of this, a high green trip proportion alone suffices hardly to make transport sustainable, not to mention the difficulties in appropriately computing the so-called "green trip proportion" (Cottrill and Derrible, 2015; Schipper, 2002). Similar with renewable energy development, sustainable transport is intertwined with a large board of questions of the urban system and requires holistic approaches to tackle with. Integrated analytical and decision-making support tools are thus needed for the make of sound urban transport policies (Praticò and Vaiana, 2012).

\section{B.8Indic 13 Overall recycling rate}

Recycling rate is a widely used indicator for assessing waste management in cities, aside indicators of waste generation and collection. Another indicator often used is "equivalent CO2 emissions" (Wilson et al., 2012). Kaila (2013) addressed the issue of potential hazardous substances in recycled and re-used materials and suggested using material flux to different types of sinks as an indicator of waste management performance. Harder et al. (2008) proposed a Maximum Practicable Recycling Rate Provision indicator for measuring the percentage of local waste that could be recycled by the existing municipal services. The European waste management programme ACR+ (De Clercq and Hannequart, 2010) makes recommendations on setting common indicators for European countries. Wilson et al. (2015) developed a set of indicators on the basis of two overlapping "triangles" defined by UN-Habitat: one triangle containing the three physical components, i.e. collection, recycling, disposal, and one triangle containing the components of governance, i.e. inclusivity, financial sustainability and proactive institutional policies.

In Western countries, the transition from landfill to integrated urban waste management has almost been accomplished, though challenges remain in terms of disparities between areas (Clarke and Maantay, 2006; Rudden, 2007). In these countries, the focus of research has shifted from technical issues relating to public services to the socio-economic factors of neighbourhood scale recycling rate. For instance, Clarke and Maantay (2006) developed a Recycling Education, Awareness, and Participation index for measuring the socio-economic variables of recycling rates in urban districts. In developing countries where municipal waste collection and recycling are largely carried out by the informal recycling sector (individual wastepickers), it is crucial to incorporate this sector into the waste management network in order to create synergies around sustainable waste management targets. This integration is believed by many scholars to offer an opportunity for win-win solutions (Linzner and Salhofer, 2014; Sim et al., 2013; Tirado-Soto and Zamberlan, 2013).

B.9Indic 15 Treatment to render solid waste non-hazardous

According to "Navigating the Eco-city" (Tianjin Eco-city, 2010), this indicator refers to the proportion of the total waste produced in the eco-city that are rendered nonhazardous. This includes: 1) treatment of dangerous and toxic waste generated by 
886

887

888

889

890

891

892

893

894

895

896

897

898

899

900

901

902

903

904

905

906

907

908

909

910

911

912

913

914

915

916

917

918

919

920

921

922

923

924

925

926

medical, industrial and construction activities; and 2) treatment of domestic through recycling, re-use, biological methods, incineration and landfill. In the book, the authors provide a further explanation relating to point 2 ):

"the first form (recycling and re-use) is considered by default as nonhazardous treatment, the second (biological) and third (incineration) forms need to meet requirement by relevant standards; (as to) the fourth form (landfill), it is obligatory to assure non-hazardous landfilling."

In a nutshell, this indicator is not restricted to hazardous solid waste as sensibly seems to be, but to all solid waste. It can therefore be reformulated more generically, for example as safe treatment and recycling of solid waste.

After this definition clarification, it will come as little surprise that the corpus shrunk very substantially after the two filters for urban (step 2 and 3), from a considerable volume following the keyword search on non-hazardous (Table 2). Among the papers retained, we can cite Farzadkia et al. (2009) who points out the absence of appropriate separation of hazardous waste from non-hazardous waste in some cities, and the paper on the European Council Directive that suggests an impermeable mineral layer for sealing non-hazardous landfills (Simon and Müller, 2004). A certain number of papers talk about healthcare waste, one paper deals with the impacts of (hazardous) waste on real estate, certain papers explore the use of incineration bottom ash as a non-hazardous material in road construction. But there is not any paper dealing with the treatment of hazardous waste from an urban planning and management perspective.

A further examination of the larger corpus before filtering on the urban criterion reveals that many studies on hazardous and non-hazardous waste originating from construction and industrial were rejected because they did not include any terms from the list of urban terms. This finding implies certain discordance between hazardous industrial and construction waste and urban waste management. Whereas the management of non-hazardous waste is the responsibility of local governments (Bacinschi et al., 2010), that of hazardous waste from the healthcare, construction and industrial sectors may remain the responsibility of the producers, which could be a matter of concern with regard to more comprehensive urban waste management.

\section{B.10 Indic 19 Renewable energy ratio}

Renewable energy (RE) ratio is widely used for the assessment of energy performance, especially in the green building and electric vehicle sectors (Begum et al., 2013; Beheiry, 2011; Chen et al., 2014; Gerylo, 2010; Januševičius and Streckienè, 2013; Monteiro and Nunes, 2015; Prata et al., 2013). Other indicators for measuring the development and outcome of RE include "investment in renewable energy" (Spalding-Fecher, 2003), and "household savings" with smart energy control systems (Mourad et al., 2014).

Xia et al. (2008) show the importance of taking into account the extra conventional energy consumed in the use of renewables in order to obtain more realistic RE 
outcomes. Otherwise the contribution of RE systems may be exaggerated, leading to "wide use of renewable energy without improving energy efficiency".

A majority of studies in our corpus assess the potential contribution of renewable energy to total energy or total electricity demand by considering the availability of RE facilities or the remaining space for the installation of further facilities. Few studies address RE from a planning perspective. Some explanatory clues can be found in the analysis by Wall et al. (2012), in which the authors identified three architectural barriers to the greater integration of solar technologies into buildings, namely: 1) limited diversity/range of designs for integration into buildings, stemming from insufficient architectural knowledge among manufacturers, 2) lack of knowledge of technology and innovative products among architects, 3) lack of tools to quantify, illustrate and communicate the outcome of including solar energy at the early design phase. We can assume by analogy that the lack of sufficient shared knowledge between planners and RE professions impedes the development of appropriate support tools for holistic RE planning and assessment. Comprehensive planning that includes a variety of city scale RE solutions seems yet to come. As Pitt and Bassett (2013) observed: “While many cities are aggressively pursuing clean energy opportunities in their municipal operations, far fewer are taking action to promote clean energy community wide."

The RE ratio is certainly a criterion that makes sense in promoting RE development, since it enables comparisons between cities and countries. Nevertheless, introducing RE facilities should be seen less as an ultimate goal than a way of tackling energy demand and GHG emission challenges. It is essential to develop holistic approaches that consider other criteria alongside RE ratio. In particular, the economic reliability of any RE planning should not be neglected. Unfortunately, there seems a paucity of literature addressing the economic viability of RE solutions, though we can cite the study of Bassiouny et al. (2011), who evaluated the cost and value of connecting wind farms to electricity grid.

\section{B.11 Indic 20 Water supply from non-traditional sources}

As might be expected, increasing the proportion of water supply from non-traditional sources, i.e. from outside the municipal supply network, is one of the major objectives of urban water management. All of the 50 papers ranked 1-2 deal with this issue. The reuse of grey/black water and rain harvesting are two major sources for non-potable water supply that receive the most attention. Research topics from our corpus include the potential of the aforementioned two sources, their drivers, and the barriers to their large-scale implementation. Wung et al. (2006) estimated that $35 \%$ of the water supply to Taipei's schools could be provided by rainwater harvesting. Garcia et al. (2015) examined the sociological drivers of rainwater harvesting for garden irrigation in a Spanish region, and found that household income, estimated water requirement and education level were direct drivers, and interest in gardening and attitudes to water conservation were indirect drivers. In the context of the USA, Steffen et al. (2013) found that the performance of household rain harvesting systems depended on cistern size and climate patterns. 
970 In Dhaka city, average household grey water was $851 /$ cap/d, i.e. $60 \%$ of the total waste 971 water generated (Biswas et al. 2012). A survey taken by Yamagata et al. (2003) showed 972 that $61 \%$ of non-potable water demand in 23 wards of the metropolitan region of Tokyo 973 was met by reclaimed water, thanks to biological treatment and ultra-filtration processes.

974 The advantages of scale have been found in the construction cost of on-site water 975 recycling systems. In the case of Tokyo, a capacity of $100 \mathrm{~m}^{3} / \mathrm{d}$ was found to be the 976 threshold for greater economic viability. In the case of Houston in humid sub-tropical 977 Texas, increasing the size of rainwater cisterns was found to increase payback (Sweeney 978 and Pate, 2015).

979 The performance of parcel rainwater harvesting systems greatly depends on climatic 980 conditions, as demonstrated by research carried in a number of regions and cities 981 (Steffen et al., 2013; Sweeney and Pate, 2015).

982 The risks to human health of using reclaimed water are found to be relatively low, 983 provided that rigorous and appropriate treatment processes are implemented for the 984 target usage (Barker-Reid et al., 2010; Sinclair et al., 2010; Wang et al., 2011; 985 Yamagata et al., 2003). Apart from routine issues, which are the object of continuous 986 research, including patterns of indoor water use (Matos et al., 2013), the quality and 987 aesthetics of reclaimed water (Biswas et al. 2012), further progress in regulations and 988 incentive strategies also seems to be a key contributor to the use of alternative water 989 sources. A change in public attitudes from acceptance of low-contact reuse only 990 (Friedler and Lahav, 2006) to acceptance of higher-contact reuse, can only be 991 achieved through greater awareness.

992

993

994

995

996

997

998

Last but not least, the request for alternative water sources should not be a substitute of water-conservation measures and encouragement of behavioral change. It is easy to understand that reuse could lead to excessive consumption because of the lower price of reused water compared with tap water, which in turn would have an adverse impact on sewage (more wastewater to be drained). From this perspective, continuing encouragement is needed both for the use of different water and of less water, in order to alleviate the pressures on surface and underground water resources.

\section{References}

Ala-Mantila, S., Heinonen, J., Junnila, S., 2014. Relationship between urbanization, direct and indirect greenhouse gas emissions, and expenditures: A multivariate analysis. Ecol. Econ. 104, 129-139. https://doi.org/10.1016/j.ecolecon.2014.04.019

Andrews, S.Q., 2008. Inconsistencies in air quality metrics: 'Blue Sky' days and $\mathrm{PM}_{10}$ concentrations in Beijing. Environ. Res. Lett. 3. https://doi.org/10.1088/17489326/3/3/034009

Bacinschi, Z., Rizescu, C.Z., Stoian, E.V., Necula, C., 2010. Waste Management Practices Used in the Attempt to Protect the Environment, in: Proceedings of the 3rd WSEAS International Conference on Engineering Mechanics, Structures, Engineering Geology, EMESEG'10. World Scientific and 
1011

1012

1013

1014

1015

1016

1017

1018

1019

1020

1021

1022

1023

1024

1025

1026

1027

1028

1029

1030

1031

1032

1033

1034

1035

1036

1037

1038

1039

1040

1041

1042

1043

1044

1045

1046

1047

1048

1049

1050

1051

1052

1053

1054

1055

1056

1057

1058

Engineering Academy and Society (WSEAS), Stevens Point, Wisconsin, USA, pp. 378-382.

Baggen, J.H., Aben, E.M.L., 2006. Automated transport in urban areas: opportunities in the Netherlands. WIT Press, pp. 453-462.

https://doi.org/10.2495/UT060451

Barker-Reid, F., Harper, G.A., Hamilton, A.J., 2010. Affluent effluent: growing vegetables with wastewater in Melbourne, Australia - a wealthy but bone-dry city. Irrig. Drain. Syst. 24, 79-94. https://doi.org/10.1007/s10795-009-9082-X

Bassiouny, E., El-Ela, A.A.A., Othman, S.A., 2011. Reliability cost/worth evaluation of bulk power system at Zafarana site in Egypt, in: 2011 IEEE PES Conference on Innovative Smart Grid Technologies - Middle East (ISGT Middle East). pp. 1-7. https://doi.org/10.1109/ISGT-MidEast.2011.6220802

Begum, S., Kumaran, P., Jayakumar, M., 2013. Use of Oil Palm Waste as a Renewable Energy Source and Its Impact on Reduction of Air Pollution in Context of Malaysia. IOP Conf. Ser. Earth Environ. Sci. 16, 012026. https://doi.org/10.1088/1755-1315/16/1/012026

Beheiry, S.M., 2011. Benchmarking Sustainable Construction Technology. Adv. Mater. Res. 347-353, 2913-2920. https://doi.org/10.4028/www.scientific.net/AMR.347-353.2913

Biswas, S.K., Rahman, Md Mafizur, Rahman, M.Y.A., Rahman, Md Mehbuboor, 2012. Applicability of domestic grey water reuse for alleviation of water crisis in Dhaka City. J. Water Reuse Desalination 2, 239-246. https://doi.org/10.2166/wrd.2012.077

Buzási, A., Csete, M., 2015. Sustainability Indicators in Assessing Urban Transport Systems. Period. Polytech. Transp. Eng. 43, 138-145. https://doi.org/10.3311/PPtr.7825

Capodaglio, A.G., Ghilardi, P., Boguniewicz-Zablocka, J., 2016. New paradigms in urban water management for conservation and sustainability. Water Pract. Technol. 11, 176-186. https://doi.org/10.2166/wpt.2016.022

Caprotti, F., Springer, C., Harmer, N., 2015. 'Eco' For Whom? Envisioning Ecourbanism in the Sino-Singapore Tianjin Eco-city, China. Int. J. Urban Reg. Res. 39, 495-517. https://doi.org/10.1111/1468-2427.12233

Chen, Z., Liu, N., Lu, X., Xiao, X., Zhang, J., 2014. Dynamic power distribution method of PV-based battery switch stations considering battery reservation. ResearchGate 29, 306-315.

Clarke, M.J., Maantay, J.A., 2006. Optimizing recycling in all of New York City's neighborhoods: Using GIS to develop the REAP index for improved recycling education, awareness, and participation. Resour. Conserv. Recycl. 46, 128148. https://doi.org/10.1016/j.resconrec.2005.06.008

Cook, D., Saviolidis, N.M., Davíðsdóttir, B., Jóhannsdóttir, L., Ólafsson, S., 2017. Measuring countries' environmental sustainability performance-The development of a nation-specific indicator set. Ecol. Indic. 74, 463-478. https://doi.org/10.1016/j.ecolind.2016.12.009

Cottrill, C.D., Derrible, S., 2015. Leveraging Big Data for the Development of Transport Sustainability Indicators. J. Urban Technol. 22, 45-64. https://doi.org/10.1080/10630732.2014.942094

Csardi, G., Nepusz, T., 2006. The igraph software package for complex network research. InterJournal Complex Syst. 1695, 1-9. 
1059

1060

1061

1062

1063

1064

1065

1066

1067

1068

1069

1070

1071

1072

1073

1074

1075

1076

1077

1078

1079

1080

1081

1082

1083

1084

1085

1086

1087

1088

1089

1090

1091

1092

1093

1094

1095

1096

1097

1098

1099

1100

1101

1102

1103

1104

1105

1106

De Clercq, O., Hannequart, J.-P., 2010. Vers un observatoire européen décentralisé des performances de gestion des déchets municipaux. Tech. Sci. Méthodes 67-75. https://doi.org/10.1051/tsm/201009067

de Jong, M., Joss, S., Schraven, D., Zhan, C., Weijnen, M., 2015. Sustainable-smartresilient-low carbon-eco-knowledge cities; Making sense of a multitude of concepts promoting sustainable urbanization. J. Clean. Prod. 109, 25-38. https://doi.org/10.1016/j.jclepro.2015.02.004

de Jong, M., Yu, C., Chen, X., Wang, D., Weijnen, M., 2013. Developing robust organizational frameworks for Sino-foreign eco-cities: comparing Sino-Dutch Shenzhen Low Carbon City with other initiatives. J. Clean. Prod. 57, 209-220. https://doi.org/10.1016/j.jclepro.2013.06.036

Devuyst, D., Hens, L., Lannoy, W. de (Eds.), 2001. How green is the city?: sustainability assessment and the management of urban environments. Columbia University Press, New York.

Ding, J., Cao, J., Xu, Q., Xi, B., Su, J., Gao, R., Huo, S., Liu, H., 2015. Spatial heterogeneity of lake eutrophication caused by physiogeographic conditions: An analysis of 143 lakes in China. J. Environ. Sci. 30, 140-147. https://doi.org/10.1016/j.jes.2014.07.029

Dormann, C.F., Fründ, J., Blüthgen, N., Gruber, B., 2009. Indices, graphs and null models: analyzing bipartite ecological networks.

Ecocity Builders, 2015. International Ecocity Framwework and Standards.

Edjabou, M.E., Jensen, M.B., Götze, R., Pivnenko, K., Petersen, C., Scheutz, C., Astrup, T.F., 2015. Municipal solid waste composition: Sampling methodology, statistical analyses, and case study evaluation. Waste Manag. 36, 12-23. https://doi.org/10.1016/j.wasman.2014.11.009

EU, 2008. Directive 2008/50/EC of the European Parliament and of the Council of 21 May 2008 on ambient air quality and cleaner air for Europe. Off. J. Eur. Communities 152, 1-43. http://eurlex.europa.eu/LexUriServ/LexUriServ.do?uri=OJ:L:2008:152:0001:0044:EN: PDF

European Comission, 2016. Urban Europe: Statistics on Cities, Towns and Suburbs. https://doi.org/10.2785/91120

Eurostat, 2016. Energy, transport and environment indicators. 2016 edition, statistical books. European Union, Luxembourg.

Farzadkia, M., Moradi, A., Mohammadi, M.S., Jorfi, S., 2009. Hospital waste management status in Iran: a case study in the teaching hospitals of Iran University of Medical Sciences. Waste Manag. Res. J. Int. Solid Wastes Public Clean. Assoc. ISWA 27, 384-389. https://doi.org/10.1177/0734242X09335703

Fiala, N., 2008. Measuring sustainability: Why the ecological footprint is bad economics and bad environmental science. Ecol. Econ. 67, 519-525. https://doi.org/10.1016/j.ecolecon.2008.07.023

Fielding, K.S., Spinks, A., Russell, S., McCrea, R., Stewart, R., Gardner, J., 2013. An experimental test of voluntary strategies to promote urban water demand management. J. Environ. Manage. 114, 343-351. https://doi.org/10.1016/j.jenvman.2012.10.027

Friedler, E., Lahav, O., 2006. Centralised urban wastewater reuse: what is the public attitude? Water Sci. Technol. 54, 423. https://doi.org/10.2166/wst.2006.605 
1107

1108

1109

1110

1111

1112

1113

1114

1115

1116

1117

1118

1119

1120

1121

1122

1123

1124

1125

1126

1127

1128

1129

1130

1131

1132

1133

1134

1135

1136

1137

1138

1139

1140

1141

1142

1143

1144

1145

1146

1147

1148

1149

1150

1151

1152

1153

1154

1155

Garcia, X., Llausàs, A., Ribas, A., Saurí, D., 2015. Watering the garden: preferences for alternative sources in suburban areas of the Mediterranean coast. Local Environ. 20, 548-564. https://doi.org/10.1080/13549839.2013.873397

Gerylo, R., 2010. The conversion of energy efficiency requirements for buildings in poland. Prague.

Gomez, G., Meneses, M., Ballinas, L., Castells, F., 2008. Characterization of urban solid waste in Chihuahua, Mexico. Waste Manag. 28, 2465-2471. https://doi.org/10.1016/j.wasman.2007.10.023

Gonzalez, A.., Baca, I.., Chanampa, M., Frutos, C.., Roman, C.., Gonzalez, J., 2011. Rethinking the green roof. A proposal of grey water phytodepuration system, in: Proceedings of the 27th International Conference on Passive and Low Energy Architecture.

Grazhdani, D., 2016. Assessing the variables affecting on the rate of solid waste generation and recycling: An empirical analysis in Prespa Park. Waste Manag. 48, 3-13. https://doi.org/10.1016/j.wasman.2015.09.028

Greed, C., 2012. Planning for sustainable transport or for people's needs. Proc. Inst. Civ. Eng. - Urban Des. Plan. 165, 219-229. https://doi.org/10.1680/udap.10.00033

Haghshenas, H., Vaziri, M., Gholamialam, A., 2015. Evaluation of sustainable policy in urban transportation using system dynamics and world cities data: A case study in Isfahan. Cities 45, 104-115. https://doi.org/10.1016/j.cities.2014.11.003

Hao, W., 2012. Ditan shengtai chengshi guocheng chuangxin yu pingjia yanjiu - yi tianjinshi weili. Tianjin University.

Harder, M.K., Stantzos, N., Woodard, R., Read, A., 2008. Development of a new quality fair access best value performance indicator (BVPI) for recycling services. Waste Manag. 28, 299-309. https://doi.org/10.1016/j.wasman.2006.12.015

Harutyunyan, N., 2012. The Move to Universal Water Metering and Volumetric Pricing in Armenia, in: ICSDEC 2012. American Society of Civil Engineers, pp. 975-984.

Hu, J., Wang, Y., Ying, Q., Zhang, H., 2014. Spatial and temporal variability of PM2.5 and PM10 over the North China Plain and the Yangtze River Delta, China. Atmos. Environ. 95, 598-609. https://doi.org/10.1016/j.atmosenv.2014.07.019

Hu, J., Ying, Q., Wang, Y., Zhang, H., 2015. Characterizing multi-pollutant air pollution in China: Comparison of three air quality indices. Environ. Int. 84, 17-25. https://doi.org/10.1016/j.envint.2015.06.014

Hu, M.-C., Wadin, J.L., Lo, H.-C., Huang, J.-Y., 2015. Transformation toward an eco-city: lessons from three Asian cities. J. Clean. Prod. https://doi.org/10.1016/j.jclepro.2015.09.033

Hui, Y., Li'ao, W., Fenwei, S., Gang, H., 2006. Urban solid waste management in Chongqing: Challenges and opportunities. Waste Manag. 26, 1052-1062. https://doi.org/10.1016/j.wasman.2005.09.005

International Ecocity Framwework and Standards, 2015.

Januševičius, K., Streckienè, G., 2013. Solar Assisted Ground Source Heat Pump Performance in Nearly Zero Energy Building in Baltic Countries. Sci. J. Riga Tech. Univ. Environ. Clim. Technol. 11. https://doi.org/10.2478/rtuect-20130007 
1156

1157

1158

1159

1160

1161

1162

1163

1164

1165

1166

1167

1168

1169

1170

1171

1172

1173

1174

1175

1176

1177

1178

1179

1180

1181

1182

1183

1184

1185

1186

1187

1188

1189

1190

1191

1192

1193

1194

1195

1196

1197

1198

1199

1200

1201

1202

1203

Jiang, T., Wu, Z., Song, Y., Liu, X., Liu, H., Zhang, H., 2013. Sustainable transport data collection and application: China Urban Transport Database. Math. Probl. Eng. 2013. https://doi.org/10.1155/2013/879752

Jin, J., Cui, Y., Zhang, L., Zhou, Y., Wu, C., 2015. Simulation and prediction analysis of urban household water demand based on multi-agent. J. Hydraul. Eng. $1387-1397$.

Joo, J.C., Oh, H.J., Ahn, H., Ahn, C.H., Lee, S., Ko, K.-R., 2015. Field application of waterworks automated meter reading systems and analysis of household water consumption. Desalination Water Treat. 54, 1401-1409. https://doi.org/10.1080/19443994.2014.889609

Joss, S., Cowley, R., de Jong, M., Müller, B., Park, B.-S., Rees, W., Roseland, M., Rydin, Y., 2015. Tomorrow's City Today: Prospects for Standardising Sustainable Urban Development. University of Westminster, London.

Joss, S., Cowley, R., Tomozeiu, D., 2013. Towards the 'ubiquitous eco-city': An analysis of the internationalisation of eco-city policy and practice. Urban Res. Pract. 6, 54-74. https://doi.org/10.1080/17535069.2012.762216

Joss, S., Tomozeiu, D., Cowley, R., 2012. Eco-city indicators: governance challenges. pp. 109-120. https://doi.org/10.2495/SC120101

Kaila, J., 2013. How do we manage consumption wastes from a skinks point of view? Espoo, Finland.

Kasperska, E., 2015. Projekt CIVITAS RENAISSANCE w Szczecinku w kontekście założeń zrównoważonego. Rocz. Ochr. Śr. Tom 17, cz.

Lee, J.H., Hancock, M.G., Hu, M.C., 2014. Towards an effective framework for building smart cities: Lessons from Seoul and San Francisco. Technol. Forecast. Soc. Change 89, 80-99. https://doi.org/10.1016/j.techfore.2013.08.033

Li, Y., Bonhomme, C., Deroubaix, J.-F., 2018. Can a Sustainable Urban Development Model be Exported ? China Perspect. 1-2, 87-97.

Ling, H.L.O., Ting, K.H., Shaharuddin, A., Kadaruddin, A., Yaakob, M.J., 2010. Air quality and human health in urban settlement: Case study of Kuala Lumpur city, in: 2010 International Conference on Science and Social Research (CSSR). pp. 510-515. https://doi.org/10.1109/CSSR.2010.5773831

Linzner, R., Salhofer, S., 2014. Municipal solid waste recycling and the significance of informal sector in urban China. Waste Manag. Res. J. Int. Solid Wastes Public Clean. Assoc. ISWA 32, 896-907. https://doi.org/10.1177/0734242X14543555

Ma, X., Shang, X., Wang, L., Dahlgren, R.A., Zhang, M., 2015. Innovative approach for the development of a water quality identification index - a case study from the Wen-Rui Tang River watershed, China. Desalination Water Treat. 55, 1400-1410. https://doi.org/10.1080/19443994.2014.925829

Matos, C., Teixeira, C.A., Duarte, A.A.L.S., Bentes, I., 2013. Domestic water uses: Characterization of daily cycles in the north region of Portugal. Sci. Total Environ. 458-460, 444-450. https://doi.org/10.1016/j.scitotenv.2013.04.018

Medved, P., 2016. A contribution to the structural model of autonomous sustainable neighbourhoods: new socio-economical basis for sustainable urban planning. J. Clean. Prod. 120, 21-30. https://doi.org/10.1016/j.jclepro.2016.01.091

Mohan, S.B., Loeffert, B., 2011. Economics of green buildings, in: Proceedings. pp. 2877-2886. 
1204

1205

1206

1207

1208

1209

1210

1211

1212

1213

1214

1215

1216

1217

1218

1219

1220

1221

1222

1223

1224

1225

1226

1227

1228

1229

1230

1231

1232

1233

1234

1235

1236

1237

1238

1239

1240

1241

1242

1243

1244

1245

1246

1247

1248

1249

1250

Moldan, B., Janoušková, S., Hák, T., 2012. How to understand and measure environmental sustainability: Indicators and targets. Ecol. Indic. 17, 4-13. https://doi.org/10.1016/j.ecolind.2011.04.033

Monteiro, J., Nunes, M.S., 2015. A Renewable Source Aware Model for the Charging of Plug-in Electrical Vehicles: SCITEPRESS - Science and and Technology Publications, pp. 51-58. https://doi.org/10.5220/0005459000510058

Mourad, M.M., Ali, A.H.H., Ookawara, S., Abdel-Rahman, A.K., Abdelkariem, N.M., 2014. An energy-efficient smart home for new cities in Egypt. pp. 115126. https://doi.org/10.2495/ARC140111

Nawaz, R., Waya, B.G.K., 2014. Estimating the amount of cold water wastage in UK households. Proc. Inst. Civ. Eng. - Water Manag. 167, 457-466. https://doi.org/10.1680/wama.12.00109

Nelson, C., 2012. China's Green Building Future | China Business Review, China buisness review.

NPC, 2002. Water law of the People's Republic of China.

Ogwueleka, T.C., 2013. Survey of household waste composition and quantities in Abuja, Nigeria. Resour. Conserv. Recycl. 77, 52-60. https://doi.org/10.1016/j.resconrec.2013.05.011

Onat, N.C., Egilmez, G., Tatari, O., 2014. Towards greening the U.S. residential building stock: A system dynamics approach. Build. Environ. 78, 68-80. https://doi.org/10.1016/j.buildenv.2014.03.030

Parris, T.M., Kates, R.W., 2003. Characterizing and measuring sustainable development. Annu. Rev. Environ. Resour., Review in Advance 28, 559-586. https://doi.org/10.1146/annurev.energy.28.050302.105551

Pastille Consortium, 2002. Indicators Into Action: Local sustainability indicator sets in their context. Final Report. Deliverable 19. London.

Phuntsho, S., Dulal, I., Yangden, D., Tenzin, U.M., Herat, S., Shon, H., Vigneswaran, S., 2010. Studying municipal solid waste generation and composition in the urban areas of Bhutan. Waste Manag. Res. J. Int. Solid Wastes Public Clean. Assoc. ISWA 28, 545-551. https://doi.org/10.1177/0734242X09343118

Pitt, D., Bassett, E., 2013. Collaborative Planning for Clean Energy Initiatives in Small to Mid-Sized Cities. J. Am. Plann. Assoc. 79, 280-294. https://doi.org/10.1080/01944363.2014.914846

Prata, J., Arsenio, E., Pontes, J.P., 2013. Moving towards the sustainable city: the role of electric vehicles, renewable energy and energy efficiency. pp. 871-883. https://doi.org/10.2495/SC130742

Praticò, F.G., Vaiana, R., 2012. Improving infrastructure sustainability in suburban and urban areas: is porous asphalt the right answer? and how? pp. 673-684. https://doi.org/10.2495/UT120571

Price, L., Zhou, N., Fridley, D., Ohshita, S., Lu, H., Zheng, N., Fino-Chen, C., 2013. Development of a low-carbon indicator system for China. Habitat Int. 37, 4 21. https://doi.org/10.1016/j.habitatint.2011.12.009

Qu, X., Li, Z., Xie, X., Sui, Y., Yang, L., Chen, Y., 2009. Survey of composition and generation rate of household wastes in Beijing, China. Waste Manag. 29, 2618-2624. https://doi.org/10.1016/j.wasman.2009.05.014

R Development Core Team, 2011. A Language and Environment for Statistical Computing. the R foundation for Statistical Computing, Vienna, Austria. 
1251

1252

1253

1254

1255

1256

1257

1258

1259

1260

1261

1262

1263

1264

1265

1266

1267

1268

1269

1270

1271

1272

1273

1274

1275

1276

1277

1278

1279

1280

1281

1282

1283

1284

1285

1286

1287

1288

1289

1290

1291

1292

1293

1294

1295

1296

1297

1298

1299

Rahman, A., Dbais, J., Imteaz, M., 2010. Sustainability of rainwater harvesting systems in multistorey residential buildings. Am. Jounral Eng. Appl. Sci., Science Publications 3, 73-82.

Ramaswami, A., Chavez, A., 2013. What metrics best reflect the energy and carbon intensity of cities? Insights from theory and modeling of 20 US cities. Environ. Res. Lett. 8, 035011. https://doi.org/10.1088/1748-9326/8/3/035011

Robles-Molina, J., Gilbert-López, B., García-Reyes, J.F., Molina-Díaz, A., 2013. Gas chromatography triple quadrupole mass spectrometry method for monitoring multiclass organic pollutants in Spanish sewage treatment plants effluents. Talanta 111, 196-205. https://doi.org/10.1016/j.talanta.2013.03.006

Rudden, P.J., 2007. Report: policy drivers and the planning and implementation of integrated waste management in Ireland using the regional approach. Waste Manag. Res. J. Int. Solid Wastes Public Clean. Assoc. ISWA 25, 270-275.

Salman, A., Al-Karablieh, E., Haddadin, M., 2008. Limits of pricing policy in curtailing household water consumption under scarcity conditions. Water Policy 10, 295-304. https://doi.org/10.2166/wp.2008.040

Schipper, L., 2002. Sustainable Urban transport in the 21st century: a new agenda. Transp. Res. Rec. J. Transp. Res. Board 12-19.

Shan, W., Yin, Y., Zhang, J., Ding, Y., 2008. Observational study of surface ozone at an urban site in East China. Atmospheric Res. 89, 252-261. https://doi.org/10.1016/j.atmosres.2008.02.014

Shen, L.-Y., Jorge Ochoa, J., Shah, M.N., Zhang, X., 2011. The application of urban sustainability indicators - A comparison between various practices. Habitat Int. 35, 17-29. https://doi.org/10.1016/j.habitatint.2010.03.006

Shiuh-Shen, C., 2013. Chinese eco-cities: A perspective of land-speculation-oriented local entrepreneurialism. China Inf. 27, 173-196. https://doi.org/10.1177/0920203X13485702

Sim, N.M., Wilson, D.C., Velis, C.A., Smith, S.R., 2013. Waste management and recycling in the former Soviet Union: the City of Bishkek, Kyrgyz Republic (Kyrgyzstan). Waste Manag. Res. J. Int. Solid Wastes Public Clean. Assoc. ISWA 31, 106-125. https://doi.org/10.1177/0734242X13499813

Simon, F.-G., Müller, W.W., 2004. Standard and alternative landfill capping design in Germany. Environ. Sci. Policy 7, 277-290. https://doi.org/10.1016/j.envsci.2004.04.002

Sinclair, M., O'Toole, J., Forbes, A., Carr, D., Leder, K., 2010. Health status of residents of an urban dual reticulation system. Int. J. Epidemiol. 39, 16671675. https://doi.org/10.1093/ije/dyq152

Spalding-Fecher, R., 2003. Indicators of sustainability for the energy sector: a South African case study. Energy Sustain. Dev. 7, 35-49.

Steffen, J., Jensen, M., Pomeroy, C.A., Burian, S.J., 2013. Water Supply and Stormwater Management Benefits of Residential Rainwater Harvesting in U.S. Cities. JAWRA J. Am. Water Resour. Assoc. 49, 810-824. https://doi.org/10.1111/jawr.12038

Su, J., Ji, D., Lin, M., Chen, Y., Sun, Y., Huo, S., Zhu, J., Xi, B., 2017. Developing surface water quality standards in China. Resour. Conserv. Recycl. 117, 294303. https://doi.org/10.1016/j.resconrec.2016.08.003

Sujauddin, M., Huda, S.M.S., Hoque, A.T.M.R., 2008. Household solid waste characteristics and management in Chittagong, Bangladesh. Waste Manag. 28, 1688-1695. https://doi.org/10.1016/j.wasman.2007.06.013 
Suzuki, H., Dastur, A., Moffatt, S., Yabuki, N., Maruyama, H., 2010. Eco ${ }^{2}$ Cities Ecological Cities as Economic Cities.pdf.

Sweeney, J.F., Pate, M., 2015. Life Cycle Costs and Field Performance Studies of a Domestic Rainwater Harvesting Application in a Humid, Sub-Tropical, Metropolitan Environment, in: World Environmental and Water Resources Congress 2015. American Society of Civil Engineers, pp. 334-343.

Tao, J., Zhang, L., Zhang, Z., Huang, R., Wu, Y., Zhang, R., Cao, J., Zhang, Y., 2015. Control of PM2.5 in Guangzhou during the 16th Asian Games period: Implication for hazy weather prevention. Sci. Total Environ. 508, 57-66. https://doi.org/10.1016/j.scitotenv.2014.11.074

Tianjin Eco-city, 2010. Daohang shengtai chengshi - Zhongxin shengtaicheng zhibiao tixi shishi moshi (Navigating Eco-city - Implementation of the KPI system of the Sino-Singapore Tianjin Eco-City), China construction industrial press. ed.

Tirado-Soto, M.M., Zamberlan, F.L., 2013. Networks of recyclable material wastepicker's cooperatives: An alternative for the solid waste management in the city of Rio de Janeiro. Waste Manag. 33, 1004-1012. https://doi.org/10.1016/j.wasman.2012.09.025

Troy, P., Holloway, D., 2004. The use of residential water consumption as an urban planning tool: a pilot study in Adelaide. J. Environ. Plan. Manag. 47, 97-114. https://doi.org/10.1080/0964056042000189826

United Nations (Ed.), 2007. Indicators of sustainable development: guidelines and methodologies, 3rd ed. ed. United Nations, New York.

Urkiaga, A., de las Fuentes, L., Bis, B., Chiru, E., Balasz, B., Hernández, F., 2008. Development of analysis tools for social, economic and ecological effects of water reuse. Desalination 218, 81-91. https://doi.org/10.1016/j.desal.2006.08.023

Vij, A., 2010. National green building assessment tool in India, in: Central Europe towards Sustainable Building "From Theory to Practice." Prague.

Wadhwa, L.., 2000. Sustainable transportation: the Key to sustainable cities, in: Brebbia, C.., Ferrante, A., Rodriguez, M., Terra, B. (Eds.), The Sustainable City: Urban Regeneration and Sustainability, International Series on Advances in Architecture. WIT Press, Southampton, UK ; Boston, pp. 281-289.

Wall, M., Probst, M.C.M., Roecker, C., Dubois, M.-C., Horvat, M., Jørgensen, O.B., Kappel, K., 2012. Achieving Solar Energy in Architecture-IEA SHC Task 41. Energy Procedia 30, 1250-1260. https://doi.org/10.1016/j.egypro.2012.11.138

Wang, X.C., Chen, R., Liu, Y.Z., Zhou, Y.B., Yang, X.D., Zhang, H.S., 2011. An independent water system with maximized wastewater reuse for non-potable purposes - Model case for future urban development. Water Pract. Technol. 6, wpt2011012. https://doi.org/10.2166/wpt.2011.012

WCED, 1987. Our common future, World Commission for Environment and Developmen. Oxford University Press.

Weiss, L., 2014. Tianjin, Eco-City, China. A bilateral institutional NEXUS for cutting-edge sustainable metropolitan development.

Wey, W.-M., Hsu, J., 2014. New Urbanism and Smart Growth: Toward achieving a smart National Taipei University District. Habitat Int. 42, 164-174. https://doi.org/10.1016/j.habitatint.2013.12.001

WHO, 2005. WHO Air quality guidelines for particulate matter, ozone, nitrogen dioxide and sulfur dioxide - Global update 2005, Summary of risk assessment. World Health Organ. Publ. 
1349

1350

1351

1352

1353

1354

1355

1356

1357

1358

1359

1360

1361

1362

1363

1364

1365

1366

1367

1368

1369

1370

1371

1372

1373

1374

1375

1376

1377
Wickham, H., 2017. stringr: Simple, Consistent Wrappers for Common String Operations.

Wickham, H., 2016. ggplot2: elegant graphics for data analysis, Second edi. ed, Use R! Springer, Cham.

Wilson, D.C., Rodic, L., Cowing, M.J., Velis, C.A., Whiteman, A.D., Scheinberg, A., Vilches, R., Masterson, D., Stretz, J., Oelz, B., 2015. 'Wasteaware' benchmark indicators for integrated sustainable waste management in cities. Waste Manag. 35, 329-342. https://doi.org/10.1016/j.wasman.2014.10.006

Wilson, D.C., Rodic, L., Scheinberg, A., Velis, C.A., Alabaster, G., 2012. Comparative analysis of solid waste management in 20 cities. Waste Manag. Res. 30, 237-254. https://doi.org/10.1177/0734242X12437569

Wung, T.-C., Lin, S.-H., Huang, S.-M., 2006. Rainwater reuse supply and demand response in urban elementary school of different districts in Taipei. Resour. Conserv. Recycl. 46, 149-167. https://doi.org/10.1016/j.resconrec.2005.06.009

Xia, C., Zhu, Y., Lin, B., 2008. Renewable energy utilization evaluation method in green buildings. Renew. Energy 33, 883-886. https://doi.org/10.1016/j.renene.2007.10.005

Yamagata, H., Ogoshi, M., Suzuki, Y., Ozaki, M., Asano, T., 2003. On-site water recycling systems in Japan. Water Sci. Technol. Water Supply 3, 149-154.

Yan, D., 2013. Urban domestic water consumption response to climate change in Urumqi city. pp. 897-904. https://doi.org/10.2495/ICESEP131181

Zhou, C., Dai, X., Wang, R., Huang, J., 2011. Indicators for evaluating sustainable communities: a review. Acta Ecol. Sin. 31, 4749-4759.

Zhou, Y., Khu, S.-T., Xi, B., Su, J., Hao, F., Wu, J., Huo, S., 2014. Status and challenges of water pollution problems in China: learning from the European experience. Environ. Earth Sci. 72, 1243-1254. https://doi.org/10.1007/s12665-013-3042-3 